Article

\title{
Smart City: Modeling Key Indicators in Serbia Using IT2FS
}

\author{
Mimica R. Milošević ${ }^{1, *}$, Dušan M. Milošević ${ }^{2}$, Dragan M. Stević ${ }^{3}$ and Ana D. Stanojević 4 \\ 1 Faculty of Business Economics and Entrepreneurship, Mitropolita Petra 8, 11000 Belgrade, Serbia \\ 2 Faculty of Electronic Engineering, University of Niš, Aleksandra Medvedeva 14, 18000 Niš, Serbia \\ 3 Department of Construction Management, Faculty of Technical Science, University of Priština, \\ Knjaza Miloša 7, 38220 Kosovska Mitrovica, Serbia \\ 4 Faculty of Civil Engineering and Architecture, University of Niš, Aleksandra Medvedeva 14, 18000 Niš, Serbia \\ * Correspondence: mimica.milosevic@gmail.com; Tel.: +381-6346-1864
}

Received: 28 May 2019; Accepted: 23 June 2019; Published: 27 June 2019

check for updates

\begin{abstract}
Previous initiatives developed for the purpose of designing and the realization of a smart, sustainable city have shown that there is no single approach to make a city "smarter" and more sustainable. Each city represents a unique system where different stakeholders, local authorities, utility companies, and citizens undertake numerous activities, creating a matrix of interactions and interdependencies. In order to understand the ecological and social contexts of the city, as well as its priority activities, history, and specific features, the establishment of an appropriate methodology to support the establishment of a sustainable and smart city has become extremely important. Our research aims to explore key indicators in the development of the concept of the smart city in Serbia, and to assess the prioritization of activities. An integral approach based on a mathematical method a hybrid fuzzy Multi-criteria decision making (MCDM) model based on Interval type-2 fuzzy sets classifies the whole system through different criteria and sub-criteria while respecting the experts' opinions. The aim is to offer modelled solutions for our country integrated with the EU by smart cities.
\end{abstract}

Keywords: smart city; Serbia; Interval type-2 fuzzy sets; key indicators

\section{Introduction}

Cities are at the heart of all sustainable urban development strategies. In cities, new job opportunities have been created and innovative technologies developed. Cities are drivers of economic development, centers of culture, science and education. Further, they also perform a significant role in fighting against climate change and the use of intelligent systems in improving the energy efficiency of urban areas [1,2]. More than half of the world's population today live in cities, and researchers predict that by 2050 urban areas will occupy $70 \%$ of the population [3-5]. Urbanization and population expansion have increased pressure on the existing infrastructure as well as problems of uncontrolled resource use, irrational energy consumption and environmental pollution. It has been considered that urban areas are responsible for $80 \%$ of carbon dioxide emissions in the atmosphere and $75 \%$ of total energy consumption, so it is necessary to transform them into more efficient entities [6]. Urbanization is caused by migration processes from rural to urban areas at the national level, as well as by international migrations [7]. Rapid urbanization has put signifficant strain on city infrastructures and requires strong strategies and innovative planning responses [8]. The increasing urban population also indicates an increase in human needs as well as environmental challenges to be addressed and is imperative for sustainable development and a higher quality of life [9]. Namely, in recent years there has been a shift in cities striving for smart targets instead of only sustainability goals [10]. The concept of a smart 
city is the result of an idea that uses advanced information and communication technologies (ICT) to improve people's lives and can be recognized as a solution to the challenges posed by the urbanization process [11]. The dominant part of the smart cities environment is the infrastructure, such as wireless communication and smart grid networks [12]. Smart cities can be considered systems that consist of people, nature, and elements of the artificial environment, using water, energy, materials, services, information, and financial flows to catalyze sustainable development, resilience and high quality of life. Flows and interactions become smart through the strategy of using information and communication infrastructures and services, in the process of transparent urban planning and management. However, smart cities are not only based on the application of appropriate technologies but also involve the active involvement of people and citizens themselves as important urban capital in creating their benefits [12]. In the global movement "Smart Cities" a complex combination of stakeholders appear at different hierarchical levels. Companies, citizens, universities, scientific institutions, management bodies, non-governmental organizations, and private investors all have a different view of the city and its future development. Despite the different visions, the common goal is for cities to be sustainable and smart [13].

The implementation of ICT in components of the city, such as transport, infrastructure, energy, culture, and entertainment, provides the ability of faster reaction to changes and overcoming the problems. This underlying idea may be simple, but in the smart city strategic planning, it often remains only at the abstract level. Most cities have defined separate strategies for transport, urban planning, economic development, and environment protection. The smart city strategy should enable the simultaneous realization of all individual goals and plans through long-term documents, initiatives, and projects of sustainable urban development. Cities vary in size, climate, demographic structure, the degree of economic development, history, culture, architecture, therefore, solutions for smart cities must take into account different requirements.

In Europe, smart cities can be found in the western countries in which, at the end of the last century, there has been a transition from the secondary to the tertiary industrial production which also includes the ICT industry. The countries in Central-Eastern and South-Eastern Europe, post-socialist countries, which are lagging behind the countries of Western Europe, are not leading either in terms of initiatives for smart city development. This is especially expressed in the Balkan countries that are not members of the European Union, including Serbia which has not created appropriate legislative, planning and technological conditions for smart urban development (Figure 1) [14].

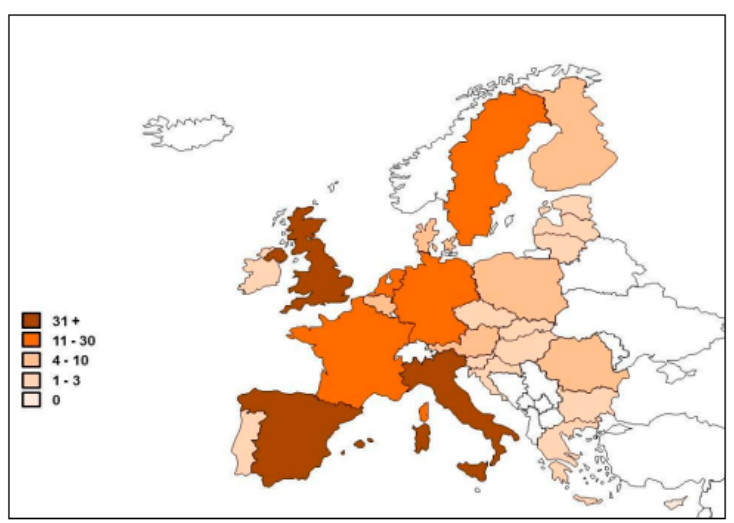

(a)

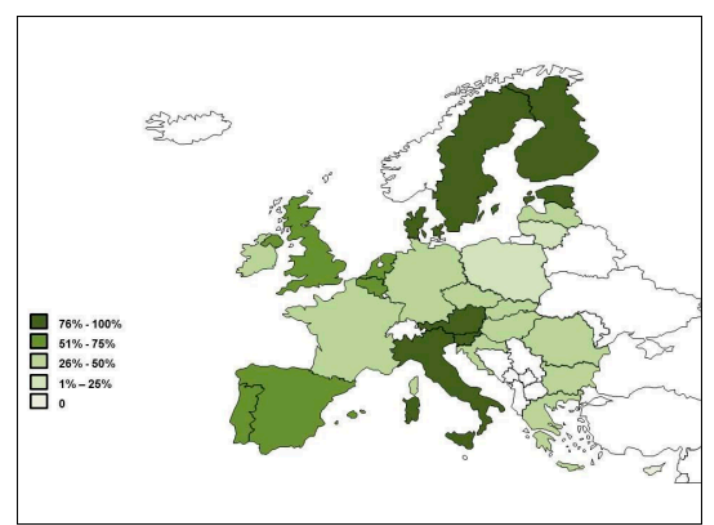

(b)

Figure 1. (a) The number of Smart Cities per country in Europe (b) The percentage of Smart Cities to cities by country in Europe [15].

Unlike the developed countries, where multidimensional decision-making represents the major challenge in transforming existing urban areas into smart ones, in Serbia, there is a need to define 
the appropriate methodology and to identify the indicators or problematic components of the city in order to enable smart city development. This paper examines the optimization of the smart cities concept development in Serbia. The aim is to rank the crucial indicators by applying the Interval type-2 fuzzy sets mathematical method, to examine their significance and contribution to the future urban development, as well as to provide measures for the development of a smart, sustainable city. The concept begins with a theoretical overview of factors affecting smart city development as well as with the analysis of the current condition in order to determine the pros and cons of the subject area. Finally, based on the use of multi-criteria analysis, the measures for the practical implementation of key indicators can be determined.

\section{Conceptualizing Smart City}

In the field of urban planning, the term "smart" appeared in the 1990s in the United States in the context of the "smart growth" movement that advocated the theory of a compact city to solve the problem of agglomeration expansion of urban areas [16]. On the other hand, the concept of a smart city was first mentioned in 1994, but related research grew in significance in 2010 after the European Union began to use the label "smart" for qualifying sustainable projects of urban development $[17,18]$. For years there were contradictions between theorists and experts with respect to finding a precise definition with which to explain the concept of the smart city.

One of the first accepted interpretations of the smart city concept was given by Hall in 2000, who said of a smart city that "a city that monitors and integrates conditions of all of its critical infrastructures, including roads, bridges, tunnels, rail, subways, airports, seaports, communications, water, power, even major buildings, can better optimize its resources, plan its preventive maintenance activities, and monitor security aspects while maximizing services to its citizens" [19]. This definition put the infrastructure systems on the forefront and did not emphasize the importance of ICT. Along with the technological development expansion, the term "smart city" was used after 2005 by technology companies to demonstrate the process of integrating ICT systems with urban infrastructure systems. The European Parliament (2014) defined smart cities as places where the traditional networks and services are made more efficient with the use of digital and telecommunication technologies, for the benefits of its inhabitants and businesses. Further an explanation, which is generally accepted to date has been given: "The city can be considered as "smart "when investments in human and social capital, and traditional (transport) and modern (ICT) communication infrastructure fuel sustainable economic growth and a high quality of life, with a wise management of natural resources through participatory governance" [20-22].

In addition to defining, many authors have dealt with the identification of variables and elements that constitute and characterize a smart city. A large number of researches highlight the use of ICT as one of the significant tools in developing the concept of smart cities [23-25]. The reason lies in the fact that the urban development of cities in the 21st century has closely linked to progress in the sector of modern technologies. For example, the ICT sector improves urban infrastructure by placing data sensors, providing the real-time information needed to manage resources. The use of ICT sensors is widespread in the cities with which we associate the epithet "smart". Mobile applications often track the movement of people to determine the preferred walking routes, an attractive location, and traffic between parts of the city, which is important for the sector of urban planning. Using big data, crowdsourcing, 5G and the Internet of Things (IoT) platforms, an existing problem is perceived from the multiple perspectives, and their integration enables the selection of the most optimal solution [26,27]. IoT data comes from different sources, passively or actively involving citizens, in one spot where they are stored, analyzed and processed, forming appropriate information that later influences the actual processes in the city. A device-to-device network system represents an add-on communication paradigm to the modern 5G wireless cellular networks [28]. Following the smart city paradigm, citizens should autonomously request and get the best service for themselves [29]. The development of cloud computing in recent years allows the virtual storage and transmission of large amounts of data. 
Using big data contributes to the creation of useful information for the various stakeholders, including citizens, visitors, local authorities and companies [30]. In this way, the inhabitants themselves provide a constant flow of information, as one of the important resources of smart cities. Besides, cities are increasingly opening free Wi-Fi networks to provide communication between all parts of the world. Smart technologies can be used successfully in buildings, and that's why we are increasingly talking about the design of smart buildings [31]. ICT also allows citizens to interact with local institutions and provides services through e-government and public administration platforms [32]. Modern technology is increasingly applied in the field of transportation systems, health services, education, economy, tourism, etc.

ICT-based infrastructure is necessary, but not sufficient for developing smart cities [33,34]. Therefore, although the concept of the smart city is consistently implemented in practice, it is not enough to develop and implement technical solutions; rather, it is necessary to enable the development of human capital through enhancing skills and improving the quality of life in urban environments for future generations. Many authors argue that it is necessary to reach a certain level of sustainability as a framework for the development of smart cities [1,35]. There is a much stronger focus on modern technology and "smartness" in the smart city frameworks compared to urban sustainability frameworks. Urban sustainability frameworks contain a large number of indicators that measure environmental sustainability. Smart urban frameworks do not have environmental indicators and emphasize social and economic aspects. The overall goal of smart cities is to improve sustainability with the help of technology. The vision of local authorities, with citizens that should be at the forefront of strategies, is crucial. The concept of a smart city means collaborative cooperation between urban planners, architects, electrical engineers, programmers, construction engineers, and social sciences experts. It covers many areas of the city in the functioning of urban planning, through energy management, water supply, public transport, e-government to the formation of attractive urban areas. The smart city is a city that meets the needs of the population and should be understood as a complex urban system composed of several components that interact with each other. The smart city concept is not unique either in terms of performances of individual system components, so it allows for the definition of the boundaries and domains of the solutions in different ways. Under the components of a smart city, we mean the most important urban domains in its creation. As the need for standardization, especially measurable and clear management in relation to concept projects, is unambiguous, the research relies on components defined by Griffinger (2007), according to which a smart city determines six criteria: smart governance, smart citizens, smart economy, smart mobility, smart livability, and smart environment. Each of these dimensions has deeply defined by sub-components, which are discussed in many types of research $[36,37]$.

\section{Research Methodology}

When moving to the details of research methodology and techniques, it is important to have a look at the basis of the research process, a set of measures or steps necessary to effectively conduct the research. Figure 2 illustrates the research process and four steps adopted in this paper. In Step 1 different influential factors in the context of smart city concept will be identified and adopted. Step 2 has focused on Serbia, as a developing country and selected region for analyzing opportunities for the future smart city development. In Phase 3, a multi-criteria analysis using the IT2FS method and the set of criteria and sub-criteria is carried out. Finally, Phase 4 highlights key indicators for smart city development and gives a proposal of measures for their practical implementation. 


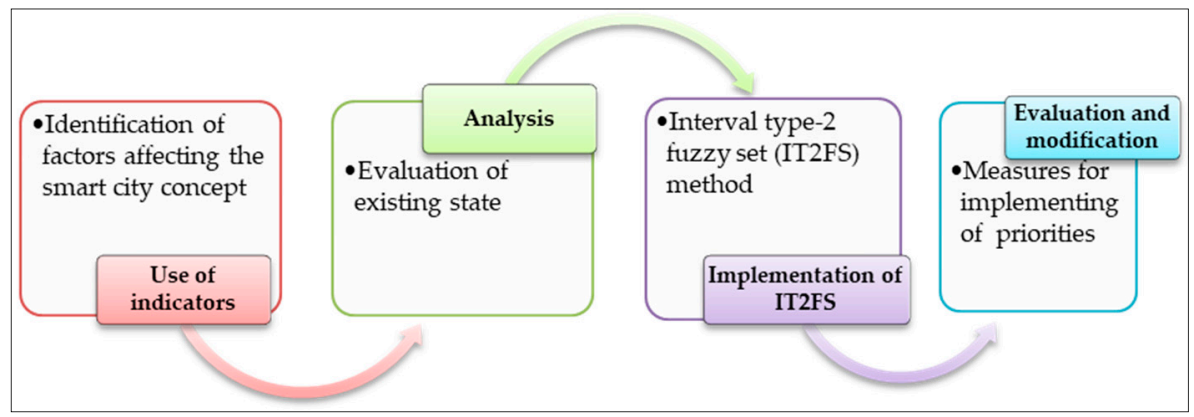

Figure 2. Four steps of research methodology.

Bearing in mind the postulates and levels of the smart city concept, as well as the key indicators, in order to succeed in establishing a smart and sustainable city, we will define the conditions for enabling important tasks.

\subsection{Identification of Factors Affecting the Smart Cities Concept}

It is important to realize the need for a vision of successful initiatives in the establishment of a smart and sustainable city. In analyzing the prior embodiment, such a broad initiative, it is necessary to include many factors. The process will fail if a clearly defined set of the goals is not provided and if the quantification and evaluation of the obtained results, which can be easily presented to citizens, are not enabled. Factors affecting the realization of the smart city concept are examined through six criteria groups (governance, citizens, environment, mobility, economy, livability) and their sub-criteria, shown in Table 1.

Table 1. Criteria and sub-criteria for smart city concept $[36,38,39]$

\begin{tabular}{|c|c|c|}
\hline Governance (G) & Citizens (C) & Environment (O) \\
\hline $\begin{array}{l}\text { Strategies and perspectives of smart city } \\
\text { development }\left(G_{1}\right)\end{array}$ & $\begin{array}{l}\text { Active participation in the local } \\
\text { community }\left(C_{1}\right)\end{array}$ & $\begin{array}{l}\text { Sustainable land planning and } \\
\text { management }\left(\mathrm{O}_{1}\right)\end{array}$ \\
\hline $\begin{array}{l}\text { Citizen participation in decision } \\
\text { making }\left(G_{2}\right)\end{array}$ & Raising civic awareness $\left(C_{2}\right)$ & $\begin{array}{l}\text { Environmental pollution control and } \\
\text { protection }\left(\mathrm{O}_{2}\right)\end{array}$ \\
\hline $\begin{array}{l}\text { Accessibility of services and } \\
\text { e-government }\left(G_{3}\right)\end{array}$ & $\begin{array}{l}\text { The high degree of qualification and } \\
\text { education }\left(C_{3}\right)\end{array}$ & Efficient use of water $\left(\mathrm{O}_{3}\right)$ \\
\hline \multirow[t]{4}{*}{$\begin{array}{l}\text { Management transparency and use of } \\
\text { open-data }\left(G_{4}\right)\end{array}$} & $\begin{array}{l}\text { Affinity to lifelong learning and } \\
\text { e-learning }\left(C_{4}\right)\end{array}$ & Use of renewable energy sources $\left(\mathrm{O}_{4}\right)$ \\
\hline & $\begin{array}{l}\text { Creativity, flexibility, and } \\
\text { open-mindedness }\left(\mathrm{C}_{5}\right)\end{array}$ & Energy efficient buildings construction $\left(\mathrm{O}_{5}\right)$ \\
\hline & Social and ethnic diversity $\left(\mathrm{C}_{6}\right)$ & $\begin{array}{l}\text { Management and protection of natural } \\
\text { resources }\left(\mathrm{O}_{6}\right)\end{array}$ \\
\hline & & Natural attractiveness of landscapes $\left(\mathrm{O}_{7}\right)$ \\
\hline Mobility (M) & Economy (E) & Livability (L) \\
\hline Integration of ICT infrastructure $\left(\mathrm{M}_{1}\right)$ & $\begin{array}{l}\text { Self-employment fostering and } \\
\text { entrepreneurship }\left(E_{1}\right)\end{array}$ & Individual safety $\left(\mathrm{L}_{1}\right)$ \\
\hline $\begin{array}{l}\text { The innovative transport system, } \\
\text { non-motorized vehicles }\left(\mathrm{M}_{2}\right)\end{array}$ & Innovations and strategic investment $\left(\mathrm{E}_{2}\right)$ & $\begin{array}{l}\text { Good and affordable housing } \\
\text { conditions }\left(\mathrm{L}_{2}\right)\end{array}$ \\
\hline \multirow[t]{6}{*}{ Local and international accessibility $\left(\mathrm{M}_{3}\right)$} & Economic opportunities $\left(\mathrm{E}_{3}\right)$ & Utilities and infrastructure equipment $\left(\mathrm{L}_{3}\right)$ \\
\hline & Productivity $\left(\mathrm{E}_{4}\right)$ & Health services $\left(\mathrm{L}_{4}\right)$ \\
\hline & $\begin{array}{l}\text { Transformation capacity and market } \\
\text { flexibility }\left(E_{5}\right)\end{array}$ & Education and training $\left(\mathrm{L}_{5}\right)$ \\
\hline & $\begin{array}{l}\text { Economy promotion and market } \\
\text { competitiveness }\left(\mathrm{E}_{6}\right)\end{array}$ & Social integration and recreation $\left(\mathrm{L}_{6}\right)$ \\
\hline & E-business, e-commerce $\left(\mathrm{E}_{7}\right)$ & Culture and tourism $\left(\mathrm{L}_{7}\right)$ \\
\hline & $\begin{array}{l}\text { Integration with national, international } \\
\text { market }\left(E_{8}\right)\end{array}$ & \\
\hline
\end{tabular}


One precondition for transforming cities into smart entities is the existence of appropriate legal frameworks at the national, regional and local level. Therefore, smart governance means working on the formation of strategies and the perspective for future urban development in a smarter way. City governance represents a multi-level ecosystem of various stakeholder groups (local governments, citizens, urban planners, etc.) that are often driven by conflicting interests [40]. A sustainable vision of a smart city cannot be achieved through a traditional governance model, based on the existence of departments responsible for individual urban sectors. The new management system must be flexible in order to combine a top-down approach with bottom-up strategies, or centrally defined rules with citizens' proposals and actions [41-43]. Many authors point out, however, that having in mind the importance of human capital for urban development, the need for established so-called citizen-centric practice (as opposed to a bureaucratic centralized government) that would meet the demands and preferences of the inhabitants themselves [44-46]. Through a collaboration between government, state authorities, institutions, and citizens, greater transparency of governance couldn't be achieved. According to the definition, smart governance is based on using ICT tools and the internet to provide information and public services on communication and collaboration between citizens and government. Further, it is associated with participation in decision making, public and social services, transparent governance, as well as political strategies and perspectives [47]. Smart citizens (people) are related to the human resource of urban areas, and as a component of a smart city, they mean people's awareness, active participation in the community, the degree of qualification and education, affinity for life-long learning and e-learning, ethnic diversity, flexibility, creativity and open-mindedness [48,49]. In this regard, the development of the smart city has a major impact on the social dimension of urban areas, not only by improving the quality of life but also through the individual development of each of citizens through education and social inclusion, regardless of ethnic, and diversity of character. Therefore, within the smart city concept, we often speak not only about local, political and urban management but also about knowledge management governance approach, which includes knowledge as the basis for linking different collaborative sides and creating sustainable strategies [50]. At the same time, scientific institutions (universities) and hi-tech companies are one of the most important actors since the first launch the development of ideas, confirm the validity of the same and contribute to the implementation of (virtual and real) technical innovative solutions and scenarios in real-life situations and processes in [51]. Lately, private investors and non-governmental organizations also appear as actors whose participation in the development of smart cities and urban areas, in general, should not be ignored. The growth of the market also affects the development of cities, so a smart economy is an inevitable part of a smart city. Smart economy obtains the development of entrepreneurship and the promotion of self-employment. This component also includes strategic investment, then various economic opportunities for employment of the citizens, productivity, transformability and market flexibility with the trends set by globalization, the promotion of economy and market competitiveness, e-commerce and e-business development, and integration with international markets. Understanding the functioning of the market to achieve the best value of a currency is an important aspect of the economic dimension of a smart city [52]. Besides, in the conditions of globalization, cities that produce new products for foreign markets or have well-developed foreign trade can compete with other cities and achieve successful productivity. Strengthening the local economy is expanding the possibilities of employment of the local population, solving the problem of unemployment, preventing the emigration of educated young people. The vast majority of cities have one or two drivers of economic development (e.g., tourism, production, etc.) that dictate the overall view of the city's economic future. The challenge of ensuring the long-term sustainability of the environment is reflected precisely in the search for solutions for long-term economic sustainability, which involves raising alternatives to primary activities and the constant development of competences of the city and its inhabitants.

Smart mobility or transport is an extremely important urban subsystem of the city. The transport sector is responsible for consuming large amounts of energy and is one of the leading polluters in cities. In the world, still, there is a trend that people have their private motor vehicles, although they are 
directly responsible for the emission of harmful gases. Smart mobility implies the integration of ICT infrastructure in order to create an innovative transport system that regulates traffic, uses electric motor vehicles and favors pedestrian and bicycle transport. In addition, local and international accessibility of the city is also important [53,54]. Smart mobility can strengthen individual security for citizens and reduce transport costs by more efficient spending on infrastructure and motor vehicles $[55,56]$. Improving the urban traffic system is one of the important aspects of smart management and should be realized through the implementation of various measures and actions [57]. The most important aspect of smart mobility is the shift from the individual private ownership of a motor vehicle to an increase in the use of public transport [58]. Automating cars and using non-stop traffic has become a priority, which is why it is actively working to improve public transport and provide car and bicycle rental opportunities [59,60]. Smart mobility implies smart infrastructure, the networking of motor vehicles, and the introduction of sensors used to track vehicles in line with traffic congestion in real time [61]. In addition, there is a tendency for the promotion of electric vehicles on the global market, in order to reduce the emissions of harmful gases.

The smart city concept has developed with the tendency to raise the quality of life in the city to a higher level. Livability as one precondition for the development of a smart city represents a backbone for improving the quality of citizens' life and their well-being [62,63]. The quality of life in the city for every individual is reflected in his individual safety and security, the possession of funds for affordable housing, the availability of services, infrastructure, health institutions, education opportunities in secondary and higher education institutions, recreation facilities and the use of cultural and touristic contents. Smart livability means the implementation of modern technologies within each of the mentioned segments in the life of citizens. This is primarily reflected in the field of education, health services, culture, and tourism sectors. Smart education, in the framework of a modern urban environment, is considered to be intercultural and should go beyond sociological, cultural and ethnic diversity among citizens [64]. The use of artificial intelligence is one of the ways used in smart education [65]. In the framework of culture, by the introduction of heritage digitization, the knowledge of the culture of one nation and society becomes widely available. Smart culture has accelerated the development of the concept of smart tourism. Smart tourism aims to provide an interface between visitors and destinations, characterized by a high degree of innovation using smart technologies and platforms to provide a unique experience to visitors [66].

Smart livability improves the quality of life by transforming homes, offices, transport and energy infrastructure into a smarter environment [67]. The smart environment represents an ecological aspect of the sustainability of the urban area and is focused primarily on pollution control, environmental protection, and management of the natural areas. A significant element is an efficiency and recycling, with special attention being paid to saving water, the use of renewable energy sources (RES) and construction of energy efficient and smart buildings. Nowadays, water shortage is one of the key problems of humanity and the water system is an important segment of urban areas. In order to test the quality of standing water and control the consumption of drinking water, data can be successfully collected through sensors and remote sensing images [68]. The promotion of the implementation of the RES system is gaining importance and is an inevitable part of sustainable development strategies. RES systems can be used in different urban sectors, while the most energetic form conversion is from solar energy into electrical or thermal [69]. The construction of energy-efficient buildings is becoming imperative, while smart technologies are used to improve the thermal and other comfort types of outdoor and indoor environments [70-74]. By collecting data through placed sensors, today it is possible to significantly reduce the consumption of energy while improving the quality of life in indoor work and living spaces by automating systems for heating, cooling, lighting, etc. [75-77]. 


\subsection{Operationalizing the Smart City in Serbia}

The application of smart solutions is characteristic for the countries of Western Europe, which are accompanied by strong economic development. In post-socialist countries the implementation of smart solutions is low and they are not leading in the development of smart environments. In Serbia, there are no smart cities and there are only proposals for the possibility of smart development through planning documents. Today, 28 urban settlements have the status of a city, with the capital city Belgrade as the largest one, while Novi Sad, Nis and Kragujevac stand out in size and strategic importance too. Bearing in mind their level of development of different urban sectors, migration of the population from rural areas and smaller settlements is directed at these cities at the national level. Contemporary urban plans are focused on medium-sized cities, counted between 100,000 and 500,000 inhabitants, as the biggest potential for the formation of future smart cities, while in Serbia these cities include almost all larger settlements [78-80]. The population creates the biggest pressure on Belgrade, whose area is continuously expanding and prevents the balanced development of other cities and regions, encouraging a centralized government order. Data on the density of population in the regions of Serbia shows that the city of Belgrade is inhabited with 513 people per $\mathrm{km}^{2}$, while the region of South-East Serbia is inhabited with only 60 people per $\mathrm{km}^{2}$ [81].

Privatization in Serbia started in 1989, and until 2001 it was based on non-binding property transformation, so during that period, a limited number of enterprises were privatized [82,83]. In some companies, privatization has led to the improvement of the existing business, while in others unsuccessful privatization attempts have resulted in bankruptcy and closure. All of this has reflected in the economy. Due to a reduction of budget inflows, job losses and a shortage in the manufacturing sector, Serbia is classified as a technologically and economically undeveloped European country. The economy of Serbia is unfavorable to economic structures with poor financial, natural and technological resources and requires a sustained restructuring with the growth of the gross domestic product, the development of foreign trade, the rate of employment of the population, investment and competitiveness on the international market [84]. Hierarchically, unlike the traditional centralized model of the economy, from the socialist period, the contemporary economy has been shifted to the local level of cities, with the recognition of established national economic development strategies. Local economic development in Serbia is not yet at a satisfactory level, but the precondition for its launch is achieved by the establishment of appropriate economic development offices as local authorities. The main tasks of local economic development are focused primarily on encouraging local businesses, but also individuals to self-employment and entrepreneurship, and then to attract foreign private investments.

Depopulation tendencies with a negative rate of natural increase are the crucial problem in Serbia [85]. In 2002, there were 7,500,031 inhabitants with a natural increase of -3.3 , and in 2016 that number fell to 7,058,322 inhabitants and a natural increase of -5.1 . The population aging is evident because of the decreased number of young people and an increased number of people over 65 years of age. In the period from 2006 to 2016, the percentage of children under the age of 14 dropped from $15.6 \%$ to $14.4 \%$, while the percentage of the elderly from 65 years increased from $17.2 \%$ to $19.2 \%$ [86]. The average age of the population increased from 40.7 years in 2006 to 42.9 years in 2016. Regarding the level of education, $48.9 \%$ of the population over 15 years has completed secondary school, while each sixth person has a higher education degree. In addition to low birth rates, depopulation also occurs as a result of young and educated people emigrating from the country due to dissatisfaction with the living conditions and the lack of job opportunities. Less than half of the population is economically active, and the unemployment rate in 2016 was $22.4 \%$ [87]. According to the report of the World Economic Forum in 2011, Serbia was the second country regarding the number of highly educated young people who had left it [88]. This trend is still current, and as a consequence, there is a decrease in the opportunities for the further economic development of the country. 
The quality of life in Serbia is not at an enviable level. By 1995, 98\% of the existing housing stock was privatized [89]. One of the problems is the housing affordability, which is why a large number of people has the status of a tenant or chooses an illegal construction process. Comparing the average household incomes and the average price of a housing apartment, we can conclude that buying an apartment requires between 15 and 20 years [90]. The most important social problem is poverty, which causes emigration and social segregation of the population so that the lowest social class has no funds for basic needs. Serbia is also characterized by uneven economic development in the regions, with the most developed area of Belgrade, and the weakest region of South-East Serbia.

Information-communication technologies have been developing in recent years and their implementation will reach expansion in the coming period. In 2010, an e-government portal was developed with the aim of providing information from different areas of services and services. However, statistics show that only $28.1 \%$ of people use the portal today, most often for downloading appropriate forms. Regarding the use of computers and mobile phones, Serbia does not lag behind too much for other countries. In 2006, the computer occupied $26.5 \%$ of the population, while in 2016 the percentage was 65.8 [81]. Nevertheless, $27.2 \%$ of residents have never used a computer before, including older people and people living in rural areas. There have not been any cloud services in Serbia yet, with only $19.1 \%$ of the population using some of them to store and share large data. The ICT sector is regarded as one of the most important sectors for the future sustainable development of Serbia. Therefore, the demand for IT engineers is growing, and the last two years have seen progress made with a project to re-train the population in this sector.

In Serbia, there is a problem of inadequate management of natural resources and their use in an unsustainable way. Serbia has good amounts of drinking water, but its use is irrational. Inappropriate waste management is one of the most serious problems in the country and it directly threatens the quality of the environment, disrupting the ecological integrity of the land, water, and air. Wild landfills are frequent and undefined waste management and recycling primary challenges. Air quality is endangered by the increase in the number of motor vehicles in urban areas. Non-renewable energy sources that are directly responsible for creating the effect of global warming are still used. Serbia has potentials for the use of renewable energy sources, primarily solar energy, but the degree of their use is extremely low due to higher initial investments [91]. Since the adoption of the Gazette on Energy Efficiency, the energy efficiency problems in new and existing facilities have been partly solved. Table 2 summarizes the key challenges for the citizens in Serbia, in the process of smart city concept development, viewed through its six basic components.

The theme of the concept of smart cities is a more and more popular topic in Serbia, which is actively promoted through the media to the general public in recent years. Building the digitized communities of the future, i.e., smart and safe towns, is one of the objectives of the Government of Serbia, which will be enabled, inter alia, by the Regulation on the Establishment of the Program for Support to Innovative Capacity Building of Local Self-Government Units in the Territory of the Republic of Serbia for 2019 ("Official Gazette of the Republic of Serbia", No. 33/2019). This Program is planning a new wave of technological innovations aimed at raising the capacity of cities and municipalities, which will enable the construction of smart and safe cities in the future.

When analyzing the existing situation, different areas for starting a smart city are analyzed, such as improving urban sustainability and environmental quality. The focus of these analyses should be shifted from approaches to direct ecological quality in holistic and long-term sustainability considerations. The development of key performance indicators for the city performance measurement system has begun to determine the needs of cities and citizens with smart urban performance measurements. 
Table 2. Challenges in Serbia seen through smart city components.

\begin{tabular}{|c|c|c|}
\hline Governance & Citizens & Environment \\
\hline $\begin{array}{l}\text { The non-existence of strategies for } \\
\text { smart city development }\end{array}$ & $\begin{array}{l}\text { Limited participation in the } \\
\text { local community }\end{array}$ & $\begin{array}{l}\text { No sustainable management for } \\
\text { brownfield issue }\end{array}$ \\
\hline $\begin{array}{l}\text { Absence of the possibility to } \\
\text { launch civic } \\
\text { initiatives/non-participation of } \\
\text { citizens in local decision-making }\end{array}$ & Undeveloped awareness & $\begin{array}{l}\text { Limited implementation of measures } \\
\text { of environment protection/lack of } \\
\text { wastewater treatment } \\
\text { system/pollution caused by motor } \\
\text { traffic and industry }\end{array}$ \\
\hline Partial development of open data & $\begin{array}{l}\text { Medium degree of qualification, } \\
\text { education/highly educated } \\
\text { people emigration }\end{array}$ & $\begin{array}{l}\text { Inability to control water consumption } \\
\text { in old objects }\end{array}$ \\
\hline \multirow[t]{4}{*}{$\begin{array}{l}\text { Partial transparency in urban } \\
\text { management }\end{array}$} & No motivation for life-long learning & Poor implementation of RES \\
\hline & $\begin{array}{l}\text { Creativity, flexibility, and } \\
\text { open-mindedness of people }\end{array}$ & $\begin{array}{l}\text { The non-existence of high-energy } \\
\text { buildings/application of energy } \\
\text { efficiency measures limited to only } \\
\text { new facilities }\end{array}$ \\
\hline & $\begin{array}{l}\text { High social diversity/low } \\
\text { ethnic diversity }\end{array}$ & The problem of wild landfills \\
\hline & & Natural attractiveness \\
\hline Mobility & Economy & Livability \\
\hline $\begin{array}{l}\text { Insufficiently developed ICT } \\
\text { infrastructure }\end{array}$ & Low degree of entrepreneurship & Insecurity and violence \\
\hline $\begin{array}{l}\text { Urban unpredictable cycling } \\
\text { routes/favoring motor vehicles }\end{array}$ & $\begin{array}{l}\text { Insufficient investment in new } \\
\text { technologies }\end{array}$ & $\begin{array}{l}\text { Inadequate living/housing conditions } \\
\text { due to poverty }\end{array}$ \\
\hline \multirow[t]{5}{*}{$\begin{array}{l}\text { Good local and international } \\
\text { accessibility }\end{array}$} & $\begin{array}{l}\text { Economic inequality } \\
\text { unemployment/uneven development } \\
\text { of the economy by regions }\end{array}$ & $\begin{array}{l}\text { Good development of utilities and } \\
\text { infrastructure equipment }\end{array}$ \\
\hline & Undeveloped manufacturing sector & Good development of health services \\
\hline & No market flexibility & $\begin{array}{l}\text { No programs for the education of } \\
\text { existentially endangered persons }\end{array}$ \\
\hline & Lack of market competitiveness & Limited social integration \\
\hline & Poor development of e-business & $\begin{array}{l}\text { High potentials in tourism and } \\
\text { culture/low promotion of them }\end{array}$ \\
\hline
\end{tabular}

\subsection{Fuzzy Hybrid Model}

Multi-Criteria Decision Making: A Hybrid Fuzzy MCDM Model Based on Interval Type-2 Fuzzy Sets

Zadeh [92] introduces the theory of fuzzy sets and addresses the vagueness and imprecision of human thought and language. A fuzzy set, also called type-1 fuzzy set (T1FS), represents a class of objects of a continuum of membership grades. It has characterized by a membership (characteristic) function assigning to each object a membership grade in the range of zero and one. Zadeh [93] also introduced fuzzy set type-2 (T2FS) as an extension of T1FS. T2FS can convey more degrees of uncertainty thus providing more robust results and therefore enabling adequate modeling on uncertain environments [94-96]. General T2FS is usually not used in real applications due to the complexity of computational operations [95]. Instead of a type of general T2FS, interval type-2 fuzzy set IT2FS, we introduced allowing considerable simplification for computation while conveying a higher degree of uncertainty than T1FS, thus providing more accurate and robust results $[97,98]$. Therefore, IT2FS has widely used in numerous applications [99].

A systematic review of MCDM techniques based on IT2FS in literature is presented in [100], and specifically for industrial applications of IT2FS and systems in [96]. Additionally, Castillo and Melin $[101,102]$ reviewed the design and optimization of the IT2FS controllers and IT2FS optimization 
based on bio-inspired methods. The following section provides the basic definitions of type-2 fuzzy sets and trapezoidal IT2FS [94,102-104].

Type-2 fuzzy sets are defined as follows:

$$
\widetilde{\widetilde{A}}=\left\{\left((x, u), \mu_{\widetilde{A}}(x, u)\right) \forall x \in X, \forall u \in J_{x} \in[0,1], 0 \leq \mu_{\widetilde{A}}(x, u) \leq 1\right\}
$$

where $J_{x}$ denotes an interval in [0,1]. Interval type-2 fuzzy set with the trapezoidal form of the membership function has graphically represented in Figure 3.

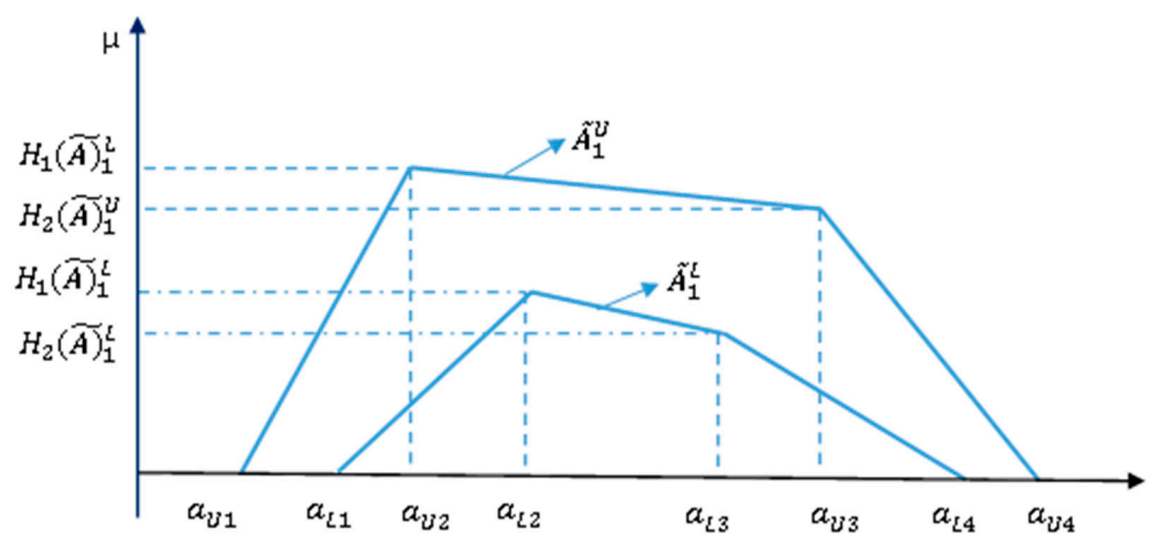

Figure 3. Graphical representation of IT2FS: The upper trapezoidal membership function $\widetilde{A}_{1}^{U}$, the lower trapezoidal membership function $\widetilde{A}_{1}^{L}$ of the IT2FS $\widetilde{\widetilde{A}}_{1}$.

The upper and lower membership functions of a trapezoidal IT2FS are type- 1 membership functions and are defined as follows:

$$
\widetilde{\widetilde{A}_{i}}=\left(\widetilde{A}_{i}^{U}, \widetilde{A}_{i}^{L}\right)=\left(\left(a_{i 1}^{U}, a_{i 2}^{U}, a_{i 3}^{U}, a_{i 4}^{U} ; H_{1}\left(\widetilde{A}_{i}^{U}\right), H_{2}\left(\widetilde{A}_{i}^{U}\right)\right),\left(a_{i 1}^{L}, a_{i 2}^{L}, a_{i 3}^{L}, a_{i 4}^{L} ; H_{1}\left(\widetilde{A}_{i}^{L}\right), H_{2}\left(\widetilde{A}_{i}^{L}\right)\right)\right),
$$

for $j=1,2 ; 1 \leq i \leq n$, where $\widetilde{A}_{i}^{U}$ and $\widetilde{A}_{i}^{L}$ are fuzzy sets of type-1. Numbers $a_{i 1}^{U}, a_{i 2}^{U}, a_{i 3^{\prime}}^{U}, a_{i 4}^{U}$ and $a_{i 1}^{L}, a_{i 2}^{L}, a_{i 3}^{L}, a_{i 4}^{L}$ represent the reference points of the IT2FS, while $H_{j}\left(\widetilde{A}_{i}^{U}\right)$ and $H_{j}\left(\widetilde{A}_{i}^{L}\right)$, belong to the interval $[0,1]$, denote the values of the elements in the upper and lower trapezoidal membership functions.

Saaty has developed the analytical hierarchical process (AHP) which belongs to the class multi-criteria decision-making method in [105]. In the fuzzy-AHP proposed by Buckley [106], the pairwise comparisons in the judgment matrix are fuzzy numbers that are modified according to the designer's emphasis. The procedure uses fuzzy arithmetic and $\alpha$-cuts and calculates a sequence of weight vectors and the corresponding set of scores. In that manner, we obtain one composite score that is the average of these fuzzy scores. Kahraman et al. involve the AHP method based on IT2FS in [107]. This method is then used to model linguistic expert judgments in [108].

In this paper, we use addition, subtraction, and multiplication with trapezoidal IT2FS as defined in $[109,110]$. The method using the interval type-2 fuzzy sets aims to manage the uncertainty in a more comprehensive way [111].

The algorithm as described below:

Step 1: Construct the fuzzy evaluation matrices $\widetilde{\widetilde{A}}$, (Equation (3)) for all considered preference criteria as follows:

$$
\widetilde{\widetilde{A}}=\left[\begin{array}{cccc}
1 & \widetilde{\widetilde{a}}_{12} & \ldots & \widetilde{\widetilde{a}}_{1 n} \\
\frac{1}{\widetilde{\widetilde{a}}_{12}} & 1 & \ldots & \widetilde{\widetilde{a}}_{2 n} \\
\vdots & \vdots & \ddots & \vdots \\
\frac{1}{\widetilde{\widetilde{a}}_{1 n}} & \frac{1}{\overline{\widetilde{a}}_{2 n}} & \ldots & 1
\end{array}\right]
$$


where,

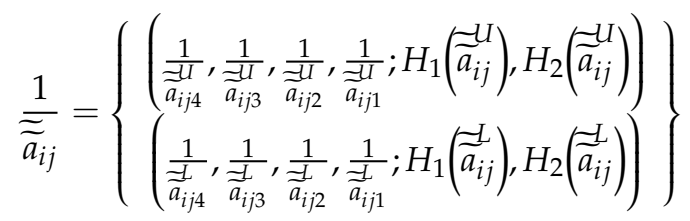

Linguistic terms and corresponding IT2FS used in the algorithm have presented in Table 3.

Table 3. Definition of interval type-2 fuzzy scale of the linguistic variables.

\begin{tabular}{ccc}
\hline Linguistic Variables & \multicolumn{2}{c}{ Trapezoidal Interval Fuzzy Scales } \\
\hline Equally important $(\mathrm{EI})$ & Upper T1FS & Lower T1FS \\
Intermediate value $\left(\mathrm{IV}_{1}\right)$ & $(1,1,1,1,1,1)$ & $(1,1,1,1,0.9,0.9)$ \\
Moderately-More important $(\mathrm{MMI})$ & $(1,3 / 2,5 / 2,3,1,1)$ & $(5 / 4,3 / 2,5 / 2,11 / 4,0.9,0.9)$ \\
Intermediate value $\left(\mathrm{IV}_{2}\right)$ & $(2,5 / 2,7 / 2,4,1,1)$ & $(9 / 4,5 / 2,7 / 2,15 / 4,0.9,0.9)$ \\
Strongly-More important (SMI) & $(4,7 / 2,9 / 2,5,1,1)$ & $(13 / 4,7 / 2,9 / 2,19 / 4,0.9,0.9)$ \\
Intermediate value $\left(\mathrm{IV}_{3}\right)$ & $(5,11 / 2,13 / 2,13,7,1,1)$ & $(17 / 4,9 / 2,11 / 2,23 / 4,0.9,0.9)$ \\
Very strongly-More important $(\mathrm{VSMI})$ & $(6,13 / 2,15 / 2,8,1,1)$ & $(25 / 4,11 / 2,13 / 2,27 / 4,0.9,0.9)$ \\
Intermediate value $\left(\mathrm{IV}_{4}\right)$ & $(7,15 / 2,17 / 2,9,1,1)$ & $(29 / 4,15 / 2,17 / 2,31 / 4,0.9,0.9)$ \\
Extremely-More important (EMI) & $(9,9,9,9,1,1)$ & $(9,9,9,9,9,0.9,0.9)$ \\
\hline
\end{tabular}

Step 2: Examine the consistency of the fuzzy evaluation matrices by using the approach proposed by Kahraman et al. [98]. The matrix consistency index $C I$ is

$$
C I=\frac{\lambda_{\max }-n}{n-1} .
$$

The principal eigenvalue $\lambda_{\max }$ has determined by the equation

$$
A w=\lambda_{\max } w,
$$

where $w$ is the eigenvector of the decision matrix of pairwise evaluation $A$. The random index RI of the matrix $A$ depends on $n$, and the corresponding values are given by Saaty [96]. Matrix $A$ is consistent if and only if $\lambda_{\max }=n$ and the matrix consistency ratio $C R$ is

$$
C R=\frac{C I}{R I}
$$

If the consistency index $C R$ is less than 0.1 , it is considered acceptable. If the consistency of $A$ is acceptable, then the consistency of $\widetilde{\widetilde{A}}$ is also acceptable.

Step 3: Calculate the geometric mean of each row as follows:

$$
\left.\widetilde{\widetilde{r}}=\widetilde{\widetilde{a}}_{11} \otimes \widetilde{\widetilde{a}}_{12} \otimes \ldots \otimes \widetilde{\widetilde{a}}_{1 n}\right]^{\frac{1}{n}}, \mathrm{i}=1,2, \ldots, n .
$$

where,

$$
\sqrt[n]{\widetilde{\sigma}_{i 1}}=\left(\begin{array}{c}
\left(\sqrt[n]{a_{i j 1}^{U}}, \sqrt[n]{a_{i j 2}^{U}}, \sqrt[n]{a_{i j 3}^{U}}, \sqrt[n]{a_{i j 4}^{U}} ; H_{1}\left(a_{i j}^{U}\right), H_{2}\left(a_{i j}^{U}\right)\right), \\
\left(\sqrt[n]{a_{i j 1}^{L}}, \sqrt[n]{a_{i j 2}^{L}}, \sqrt[n]{a_{i j 3}^{L}}, \sqrt[n]{a_{i j 4}^{L}} ; H_{1}\left(a_{i j}^{L}\right), H_{2}\left(a_{i j}^{L}\right)\right)
\end{array}\right) .
$$

Step 4: Calculate the fuzzy weights of each criterion:

$$
\left.\widetilde{\widetilde{w}}_{j}=\widetilde{\widetilde{r}} \otimes \widetilde{\widetilde{r}}_{1} \oplus \widetilde{\widetilde{r}}_{2} \oplus \ldots \oplus \widetilde{\widetilde{r}}_{n}\right]^{-1}, j=1,2, \ldots, n
$$

Step 5: The defuzzified value of $\widetilde{\widetilde{a}}$ is obtained using the center of area method [98] 


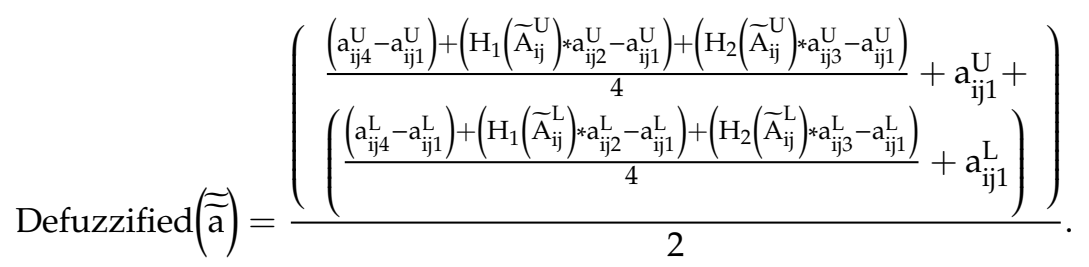

\section{Results}

In this section, we will apply the algorithm outlined in Section 3.3.

Step 1: Fuzzy evaluation matrices of criteria and sub-criteria with linguistic terms have made. Values of the corresponding IT2FS numbers have given in Tables 4-10.

We used the linguistic expressions presented in Table 3 to evaluate the importance of each criterion and sub-criterion. The obtained evaluation results are as shown in the fuzzy evaluation matrices have been given for criteria and sub-criteria in Tables 4-10.

Table 4. Fuzzy evaluation matrix for smart city criteria.

\begin{tabular}{ccccccc}
\hline & $\mathbf{G}$ & $\mathbf{C}$ & $\mathbf{E}$ & $\mathbf{L}$ & $\mathbf{M}$ & $\mathbf{O}$ \\
\hline $\mathbf{G}$ & EI & IV1 & MMI & MMI & IV2 & IV2 \\
$\mathbf{C}$ & $1 /$ IV1 & EI & IV1 & IV1 & MMI & MMI \\
$\mathbf{E}$ & $1 / \mathrm{MMI}$ & $1 /$ IV1 & EI & EI & IV1 & IV1 \\
$\mathbf{L}$ & $1 / \mathrm{MMI}$ & $1 /$ IV1 & $1 / \mathrm{EI}$ & EI & IV1 & IV1 \\
$\mathbf{M}$ & $1 /$ IV2 & $1 / \mathrm{MMI}$ & $1 /$ IV1 & $1 /$ IV1 & EI & EI \\
$\mathbf{O}$ & $1 /$ IV2 & $1 / \mathrm{MMI}$ & $1 /$ IV1 & $1 /$ IV1 & $1 /$ EI & EI \\
\hline
\end{tabular}

$\mathrm{CI}=0.008 ; \mathrm{CR}=0.007$.

Table 5. Fuzzy evaluation matrix for governance sub-criteria.

\begin{tabular}{|c|c|c|c|c|}
\hline & $\mathrm{G}_{1}$ & $\mathrm{G}_{2}$ & $\mathrm{G}_{3}$ & $\mathrm{G}_{4}$ \\
\hline $\mathrm{G}_{1}$ & EI & IV1 & MMI & MMI \\
\hline $\mathrm{G}_{2}$ & 1/IV1 & EI & IV1 & IV1 \\
\hline $\mathrm{G}_{3}$ & 1/MMI & 1/IV1 & EI & EI \\
\hline $\mathrm{G}_{4}$ & 1/MMI & 1/IV1 & $1 / \mathrm{EI}$ & EI \\
\hline
\end{tabular}

Table 6. Fuzzy evaluation matrix for smart citizen's sub-criteria.

\begin{tabular}{ccccccc}
\hline & $\mathrm{C}_{1}$ & $\mathrm{C}_{2}$ & $\mathrm{C}_{3}$ & $\mathrm{C}_{4}$ & $\mathrm{C}_{5}$ & $\mathrm{C}_{6}$ \\
\hline $\mathrm{C}_{1}$ & EI & IV1 & MMI & MMI & SMI & VSMI \\
$\mathrm{C}_{2}$ & $1 / \mathrm{IV} 1$ & EI & IV1 & IV1 & IV2 & IV3 \\
$\mathrm{C}_{3}$ & $1 / \mathrm{MMI}$ & $1 / \mathrm{IV} 1$ & EI & EI & MMI & SMI \\
$\mathrm{C}_{4}$ & $1 / \mathrm{MMI}$ & $1 / \mathrm{IV} 1$ & $1 / \mathrm{EI}$ & $\mathrm{EI}$ & $\mathrm{MMI}$ & $\mathrm{SMI}$ \\
$\mathrm{C}_{5}$ & $1 / \mathrm{SMI}$ & $1 / \mathrm{IV} 2$ & $1 / \mathrm{MMI}$ & $1 / \mathrm{MMI}$ & $\mathrm{EI}$ & $\mathrm{MMI}$ \\
$\mathrm{C}_{6}$ & $1 / \mathrm{VSMI}$ & $1 / \mathrm{IV} 3$ & $1 / \mathrm{SMI}$ & $1 / \mathrm{SMI}$ & $1 / \mathrm{MMI}$ & $\mathrm{EI}$ \\
\hline \multicolumn{7}{c}{$\mathrm{CI}=0.029 ; \mathrm{CR}=0.023}$.
\end{tabular}

Table 7. Fuzzy evaluation matrix for smart economy sub-criteria.

\begin{tabular}{|c|c|c|c|c|c|c|c|c|}
\hline & $\mathrm{E}_{1}$ & $\mathrm{E}_{2}$ & $E_{3}$ & $\mathrm{E}_{4}$ & $E_{5}$ & $\mathrm{E}_{6}$ & $\mathrm{E}_{7}$ & $\mathrm{E}_{8}$ \\
\hline$E_{1}$ & EI & IV1 & IV1 & MMI & IV2 & IV2 & SMI & SMI \\
\hline$E_{2}$ & 1/IV1 & EI & EI & IV1 & MMI & MMI & IV2 & IV2 \\
\hline$E_{3}$ & 1/IV1 & 1/EI & EI & IV1 & MMI & MMI & IV2 & IV2 \\
\hline $\mathrm{E}_{4}$ & 1/MMI & 1/IV1 & 1/IV1 & EI & IV1 & IV1 & MMI & MMI \\
\hline $\mathrm{E}_{5}$ & 1/IV2 & 1/MMI & 1/MMI & 1/IV1 & EI & EI & IV1 & IV1 \\
\hline $\mathrm{E}_{6}$ & 1/IV2 & 1/MMI & 1/MMI & 1/IV1 & $1 / \mathrm{EI}$ & EI & IV1 & IV1 \\
\hline$E_{7}$ & 1/SMI & 1/IV2 & 1/IV2 & 1/MMI & 1/IV1 & 1/IV1 & EI & EI \\
\hline$E_{8}$ & 1/SMI & 1/IV2 & 1/IV2 & 1/MMI & 1/IV1 & 1/IV1 & $1 /$ EI & EI \\
\hline
\end{tabular}


Table 8. Fuzzy evaluation matrix for smart livability sub-criteria.

\begin{tabular}{|c|c|c|c|c|c|c|c|}
\hline & $\mathbf{L}_{1}$ & $\mathbf{L}_{2}$ & $\mathbf{L}_{3}$ & $\mathbf{L}_{4}$ & $\mathrm{~L}_{5}$ & $\mathrm{~L}_{6}$ & $\mathrm{~L}_{7}$ \\
\hline $\mathbf{L}_{1}$ & EI & IV1 & IV1 & MMI & IV2 & SMI & SMI \\
\hline $\mathrm{L}_{2}$ & 1/IV1 & EI & EI & IV1 & MMI & IV2 & IV2 \\
\hline $\mathrm{L}_{3}$ & 1/IV1 & 1/EI & EI & IV1 & MMI & IV2 & IV2 \\
\hline $\mathbf{L}_{4}$ & 1/MMI & 1/IV1 & 1/IV1 & EI & IV1 & MMI & MMI \\
\hline $\mathrm{L}_{5}$ & 1/IV2 & 1/MMI & 1/MMI & 1/IV1 & EI & IV1 & IV1 \\
\hline $\mathrm{L}_{6}$ & 1/SMI & 1/IV2 & 1/IV2 & 1/MMI & 1/IV1 & EI & EI \\
\hline $\mathrm{L}_{7}$ & 1/SMI & 1/IV2 & $1 /$ IV2 & 1/MMI & 1/IV1 & $1 / \mathrm{EI}$ & EI \\
\hline
\end{tabular}

Table 9. Fuzzy evaluation matrix for smart mobility sub-criteria.

\begin{tabular}{cccc}
\hline & $\mathbf{M}_{\mathbf{1}}$ & $\mathbf{M}_{\mathbf{2}}$ & $\mathbf{M}_{\mathbf{3}}$ \\
\hline $\mathbf{M}_{\mathbf{1}}$ & $\mathrm{EI}$ & $\mathrm{IV} 1$ & $\mathrm{IV} 2$ \\
$\mathbf{M}_{\mathbf{2}}$ & $1 / \mathrm{IV} 1$ & $\mathrm{EI}$ & $\mathrm{MMI}$ \\
$\mathbf{M}_{\mathbf{3}}$ & $1 / \mathrm{IV} 2$ & $1 / \mathrm{MMI}$ & $\mathrm{EI}$ \\
\hline \multicolumn{4}{c}{$\mathrm{CI}=0.009 ; \mathrm{CR}=0.016}$.
\end{tabular}

Table 10. Fuzzy evaluation matrix for smart environment sub-criteria.

\begin{tabular}{|c|c|c|c|c|c|c|c|}
\hline & $\mathrm{O}_{1}$ & $\mathrm{O}_{2}$ & $\mathrm{O}_{3}$ & $\mathrm{O}_{4}$ & $\mathrm{O}_{5}$ & $\mathrm{O}_{6}$ & $\mathrm{O}_{7}$ \\
\hline $\mathrm{O}_{1}$ & EI & IV1 & MMI & MMI & IV2 & SMI & VSMI \\
\hline $\mathrm{O}_{2}$ & 1/IV1 & EI & IV1 & IV1 & MMI & IV2 & IV3 \\
\hline $\mathrm{O}_{3}$ & 1/MMI & 1/IV1 & EI & EI & IV1 & MMI & SMI \\
\hline $\mathrm{O}_{4}$ & 1/MMI & 1/IV1 & 1/EI & EI & IV1 & MMI & SMI \\
\hline $\mathrm{O}_{5}$ & 1/IV2 & $1 / \mathrm{MMI}$ & $1 /$ IV1 & 1/IV1 & EI & IV1 & IV2 \\
\hline $\mathrm{O}_{6}$ & 1/SMI & $1 / \mathrm{IV} 2$ & $1 / \mathrm{MMI}$ & 1/MMI & 1/IV1 & EI & MMI \\
\hline $\mathrm{O}_{7}$ & 1/VSMI & $1 /$ IV3 & 1/SMI & 1/SMI & $1 / \mathrm{IV} 2$ & 1/MMI & EI \\
\hline
\end{tabular}

Step 2: The consistency of the obtained matrices has investigated. For each matrix, the obtained values for $C I$ and $C R$ have shown in Tables 4-10. Since all values of $C R<0.1$, we see that all matrices are consistent.

Steps 3 and 4: The values of geometric mean have calculated. After that, using these values, fuzzy weights of criteria and sub-criterion have obtained. Corresponding values of trapezoidal fuzzy weights for criteria and sub-criteria have given in Table 11.

Step 5: Using Formula (11), according to the values of the fuzzy weights, defuzzified values have obtained. With $W_{C}$, we have denoted the defuzzified weights of the criteria and with $W_{S C}$ the corresponding defuzzified weights of the subcriteria.

Table 11. Fuzzy weights of trapezoidal IT2FS numbers and corresponding defuzzified weights.

\begin{tabular}{cccc}
\hline & Upper Trapeze & Lower Trapeze & Weight \\
\hline & & Smart City & $\mathbf{W}_{\mathbf{C}}$ \\
\hline G & $(0.1892,0.2675,0.4815,0.6481,1,1)$ & $(0.2268,0.2675,0.4815,0.5569,0.9,0,9)$ & 0.380552 \\
C & $(0.1092,0.1618,0.3176,0.455,1,1)$ & $(0.1343,0.1618,0.3176,0.3778,0.9,0,9)$ & 0.248436 \\
E & $(0.06882,0.09676,0.1795,0.2554,1,1)$ & $(0.08222,0.09676,0.1795,0.2124,0.9,0,9)$ & 0.142998 \\
L & $(0.06882,0.09676,0.1795,0.2554,1,1)$ & $(0.08222,0.09676,0.1795,0.2124,0.9,0,9)$ & 0.142998 \\
M & $(0.04382,0.05647,0.1003,0.147,1,1)$ & $(0.04974,0.05647,0.1003,0.1200,0.9,0,9)$ & 0.082384 \\
O & $(0.04382,0.05647,0.1003,0.147,1,1)$ & $(0.04974,0.05647,0.1003,0.1200,0.9,0,9)$ & 0.082384 \\
\hline & & Smart Governance & $\mathbf{W}_{\text {SC }}$ \\
\hline G $_{\mathbf{1}}$ & $(0.2339,0.3353,0.6052,0.8102,1,1)$ & $(0.2828,0.3353,0.6052,0.6984,0.9,0,9)$ & 0.476575 \\
$\mathbf{G}_{\mathbf{2}}$ & $(0.1256,0.1866,0.3675,0.5331,1,1)$ & $(0.1548,0.1866,0.3675,0.439,0.9,0,9)$ & 0.288254 \\
$\mathbf{G}_{\mathbf{3}}$ & $(0.08886,0.111,0.184,0.2588,1,1)$ & $(0.09953,0.111,0.184,0.2162,0.9,0,9)$ & 0.153315 \\
$\mathbf{G}_{\mathbf{4}}$ & $(0.08886,0.111,0.184,0.2588,1,1)$ & $(0.09953,0.111,0.184,0.2162,0.9,0,9)$ & 0.153315 \\
\hline
\end{tabular}


Table 11. Cont.

\begin{tabular}{|c|c|c|c|}
\hline & Upper Trapeze & Lower Trapeze & Weight \\
\hline & & Smart Citizens & $\mathbf{W}_{\mathrm{SC}}$ \\
\hline$C_{1}$ & $(0.2088,0.283,0.4742,0.6116,1,1)$ & $(0.2449,0.283,0.4742,0.5376,0.9,0,9)$ & 0.38026 \\
\hline $\mathrm{C}_{2}$ & $(0.1275,0.1787,0.3211,0.4390,1,1)$ & $(0.1522,0.1787,0.3211,0.3735,0.9,0,9)$ & 0.255274 \\
\hline $\mathrm{C}_{3}$ & $(0.09120,0.1158,0.1894,0.2546,1,1)$ & $(0.1029,0.1158,0.1894,0.2180,0.9,0,9)$ & 0.155862 \\
\hline $\mathrm{C}_{4}$ & $(0.09120,0.1158,0.1894,0.2546,1,1)$ & $(0.1029,0.1158,0.1894,0.2180,0.9,0,9)$ & 0.155862 \\
\hline $\mathrm{C}_{5}$ & $(0.03914,0.04993,0.08271,0.1112,1,1)$ & $(0.04426,0.04993,0.08271,0.0953,0.9,0,9)$ & 0.0677521 \\
\hline \multirow[t]{2}{*}{$\mathrm{C}_{6}$} & $(0.02179,0.02672,0.04131,0.05358,1,1)$ & $(0.02414,0.02672,0.04131,0.04679,0.9,0,9)$ & 0.0344498 \\
\hline & & Smart Economy & $\mathbf{W}_{\mathrm{SC}}$ \\
\hline $\mathrm{E}_{1}$ & $(0.1523,0.2146,0.3815,0.5080,1,1)$ & $(0.1824,0.2146,0.3815,0.4391,0.9,0,9)$ & 0.301873 \\
\hline $\mathrm{E}_{2}$ & $(0.1024,0.1401,0.2470,0.3365,1,1)$ & $(0.1205,0.1401,0.2470,0.2867,0.9,0,9)$ & 0.197718 \\
\hline $\mathrm{E}_{3}$ & $(0.1024,0.1401,0.2470,0.3365,1,1)$ & $(0.1205,0.1401,0.2470,0.2867,0.9,0,9)$ & 0.197718 \\
\hline $\mathrm{E}_{4}$ & $(0.05703,0.08217,0.1612,0.2367,1,1)$ & $(0.06893,0.08217,0.1612,0.1936,0.9,0,9)$ & 0.127358 \\
\hline $\mathrm{E}_{5}$ & $(0.03783,0.05192,0.09455,0.1338,1,1)$ & $(0.04456,0.05192,0.09455,0.1115,0.9,0,9)$ & 0.0757648 \\
\hline$E_{6}$ & $(0.03783,0.05192,0.09455,0.1338,1,1)$ & $(0.04456,0.05192,0.09455,0.1115,0.9,0,9)$ & 0.0757648 \\
\hline $\mathrm{E}_{7}$ & $(0.02563,0.0327,0.05679,0.08127,1,1)$ & $(0.02897,0.0327,0.05679,0.06717,0.9,0,9)$ & 0.0466518 \\
\hline \multirow[t]{2}{*}{$\mathrm{E}_{8}$} & $(0.02563,0.0327,0.05679,0.08127,1,1)$ & $(0.02897,0.0327,0.05679,0.06717,0.9,0,9)$ & 0.0466518 \\
\hline & & Smart Livability & $\mathbf{W}_{\mathrm{SC}}$ \\
\hline $\mathbf{L}_{1}$ & $(0.1648,0.2332,0.4139,0.5494,1,1)$ & $(0.1979,0.2332,0.4139,0.4758,0.9,0,9)$ & 0.327224 \\
\hline $\mathbf{L}_{2}$ & $(0.1109,0.1502,0.2610,0.3542,1,1)$ & $(0.1298,0.1502,0.2610,0.3023,0.9,0,9)$ & 0.209866 \\
\hline $\mathbf{L}_{3}$ & $(0.1109,0.1502,0.2610,0.3542,1,1)$ & $(0.1298,0.1502,0.2610,0.3023,0.9,0,9)$ & 0.209866 \\
\hline $\mathbf{L}_{4}$ & $(0.06276,0.08784,0.1682,0.2469,1,1)$ & $(0.07460,0.08784,0.1682,0.2018,0.9,0,9)$ & 0.134078 \\
\hline $\mathbf{L}_{5}$ & $(0.03926,0.0550,0.1041,0.1505,1,1)$ & $(0.04678,0.0550,0.1041,0.1241,0.9,0,9)$ & 0.0829211 \\
\hline $\mathbf{L}_{6}$ & $(0.02944,0.0370,0.06164,0.08513,1,1)$ & $(0.03305,0.0370,0.06164,0.07177,0.9,0,9)$ & 0.050878 \\
\hline \multirow[t]{2}{*}{$\mathrm{L}_{7}$} & $(0.02944,0.0370,0.06164,0.08513,1,1)$ & $(0.03305,0.0370,0.06164,0.07177,0.9,0,9)$ & 0.050878 \\
\hline & & Smart Mobility & $\mathbf{W}_{\mathrm{SC}}$ \\
\hline $\mathbf{M}_{1}$ & $(0.3132,0.4288,0.7142,0.9187,1,1)$ & $(0.3699,0.4288,0.7142,0.8082,0.9,0,9)$ & 0.572792 \\
\hline $\mathbf{M}_{2}$ & $(0.1897,0.2467,0.4228,0.591,1,1)$ & $(0.2168,0.2467,0.4228,0.4949,0.9,0,9)$ & 0.345648 \\
\hline \multirow[t]{2}{*}{$\mathbf{M}_{3}$} & $(0.08001,0.09844,0.1547,0.205,1,1)$ & $(0.08878,0.09844,0.1547,0.1768,0.9,0,9)$ & 0.128952 \\
\hline & & Smart Environment & $\mathbf{W}_{\mathrm{SC}}$ \\
\hline $\mathbf{O}_{1}$ & $(0.1859,0.2542,0.4344,0.5685,1,1)$ & $(0.2189,0.2542,0.4344,0.4957,0.9,0,9)$ & 0.347233 \\
\hline $\mathrm{O}_{2}$ & $(0.1150,0.1633,0.3001,0.4144,1,1)$ & $(0.1382,0.1633,0.3001,0.3508,0.9,0,9)$ & 0.237389 \\
\hline $\mathrm{O}_{3}$ & $(0.07815,0.1047,0.1819,0.2493,1,1)$ & $(0.09089,0.1047,0.1819,0.2115,0.9,0,9)$ & 0.146826 \\
\hline $\mathrm{O}_{4}$ & $(0.07815,0.1047,0.1819,0.2493,1,1)$ & $(0.09089,0.1047,0.1819,0.2115,0.9,0,9)$ & 0.146826 \\
\hline $\mathrm{O}_{5}$ & $(0.04614,0.06271,0.116,0.1703,1,1)$ & $(0.05396,0.06271,0.116,0.1395,0.9,0,9)$ & 0.0938462 \\
\hline $\mathrm{O}_{6}$ & $(0.03235,0.04214,0.07402,0.1048,1,1)$ & $(0.03695,0.04214,0.07402,0.08728,0.9,0,9)$ & 0.0602656 \\
\hline $\mathbf{O}_{7}$ & $(0.01820,0.0226,0.03617,0.04790,1,1)$ & $(0.02032,0.0226,0.03617,0.04137,0.9,0,9)$ & 0.0299542 \\
\hline
\end{tabular}

A graphical representation of the trapezoidal fuzzy weights of IT2FS numbers is offered in Figures 4-7.

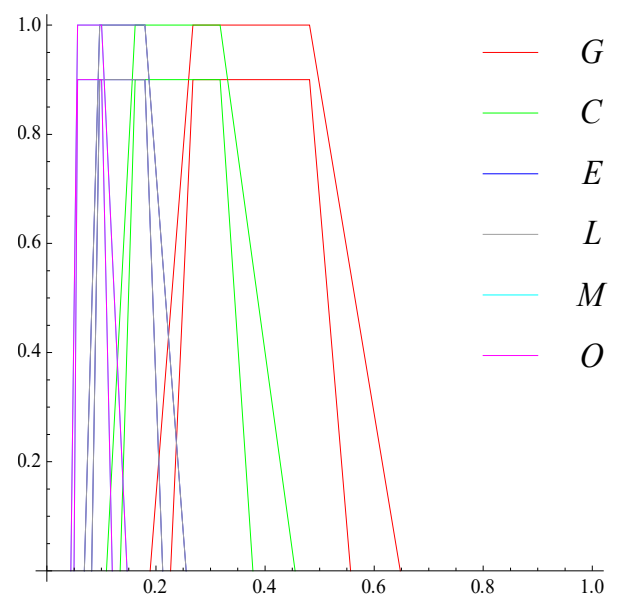

Figure 4. Graphical representation of the trapezoidal fuzzy weights for the criteria of smart city. 


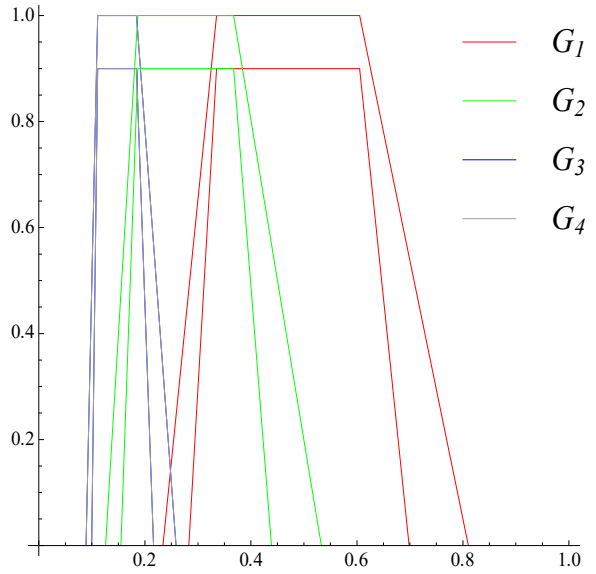

(a)

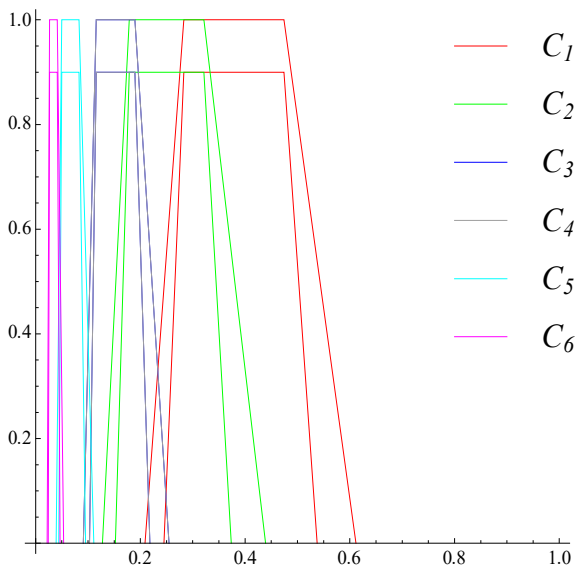

(b)

Figure 5. Graphical representation of the trapezoidal fuzzy weights for: (a) the smart governance sub-criteria (b) the smart citizens sub-criteria.

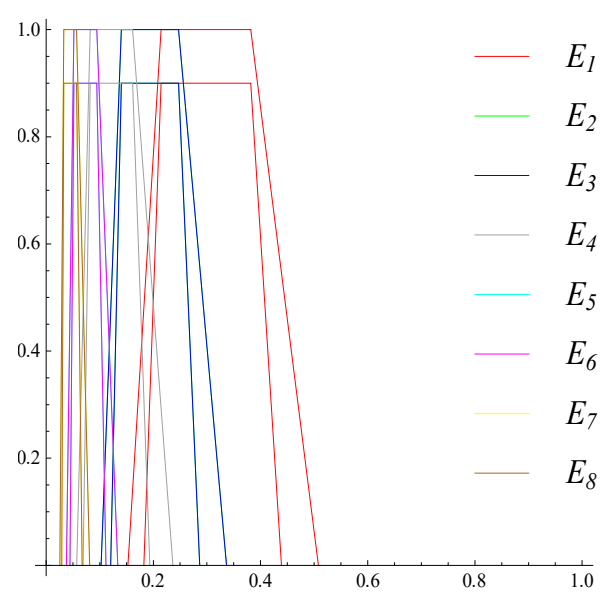

(a)

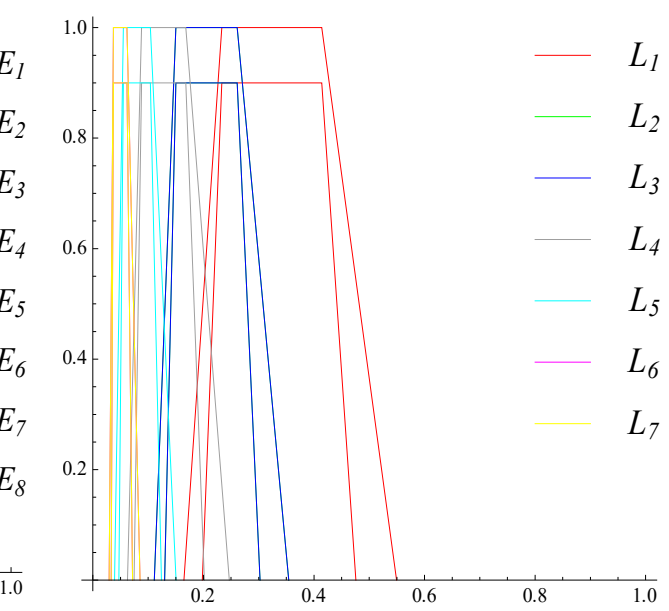

(b)

Figure 6. Graphical representation of the trapezoidal fuzzy weights for: (a) the smart economy sub-criteria (b) the smart livability sub-criteria.

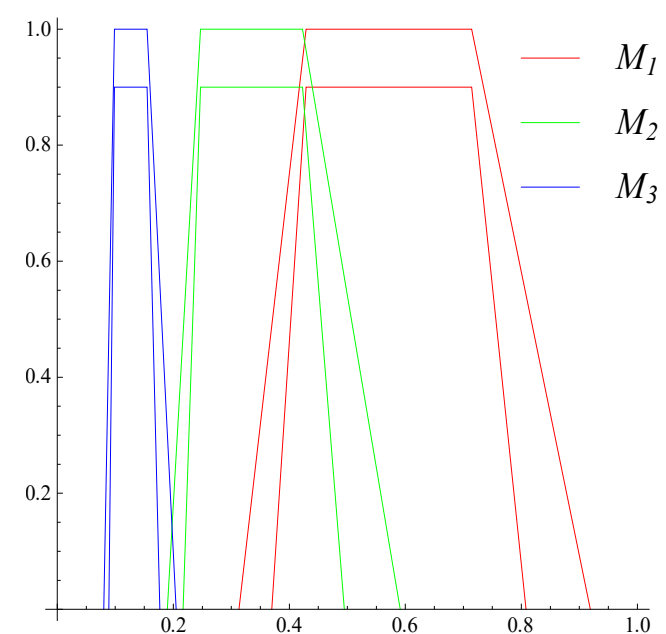

(a)

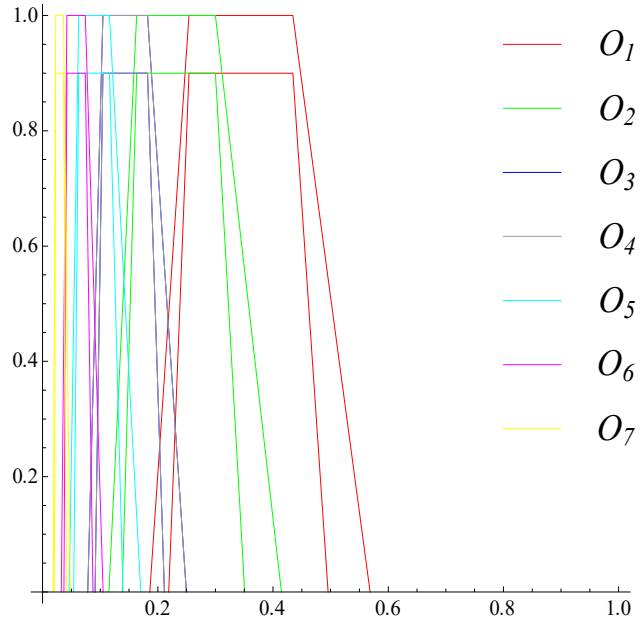

(b)

Figure 7. Graphical representation of the trapezoidal fuzzy weights for: (a) the smart mobility sub-criteria (b) the smart environment sub-criteria. 
Defuzzified weights of criteria and sub-criteria of smart city have graphically presented in Figures 8-11.

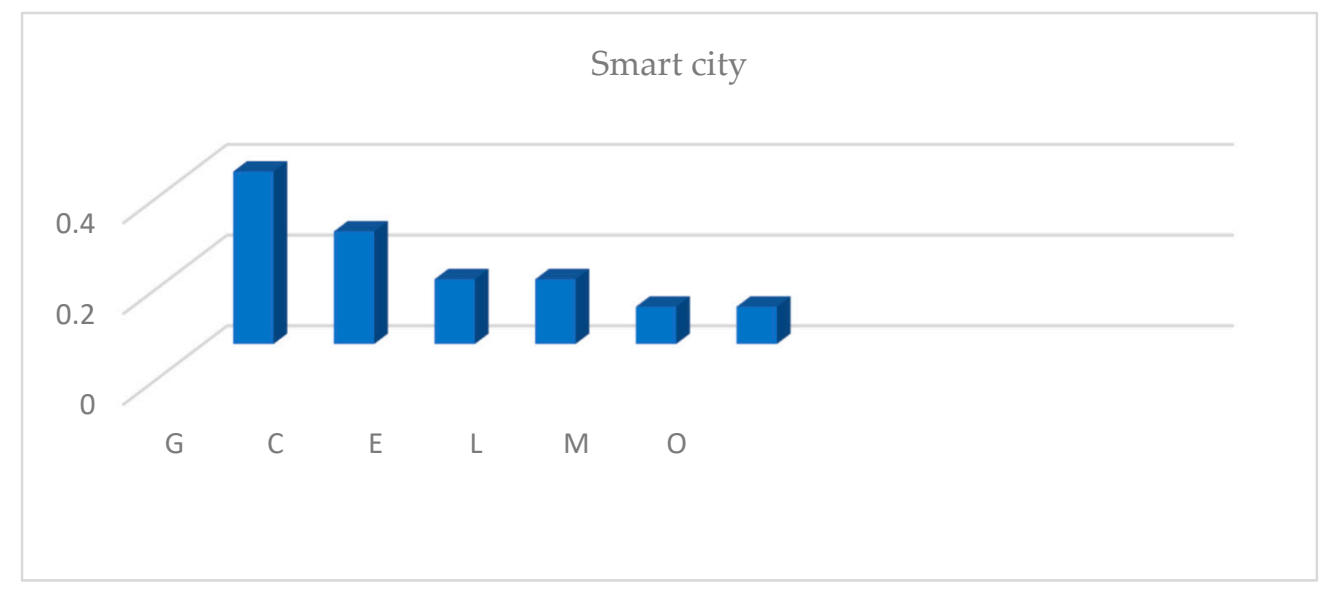

Figure 8. Graphical representation of the defuzzified weights of criteria.

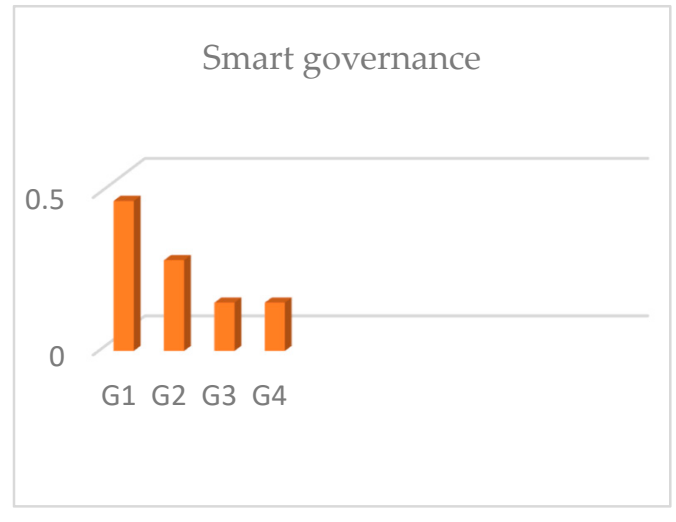

(a)

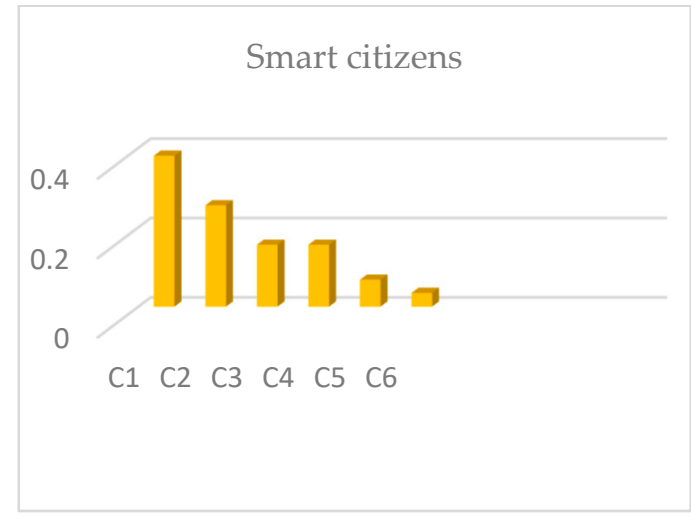

(b)

Figure 9. Graphical representation of the defuzzified weights of: (a) the smart governance sub-criteria (b) the smart citizens sub-criteria.

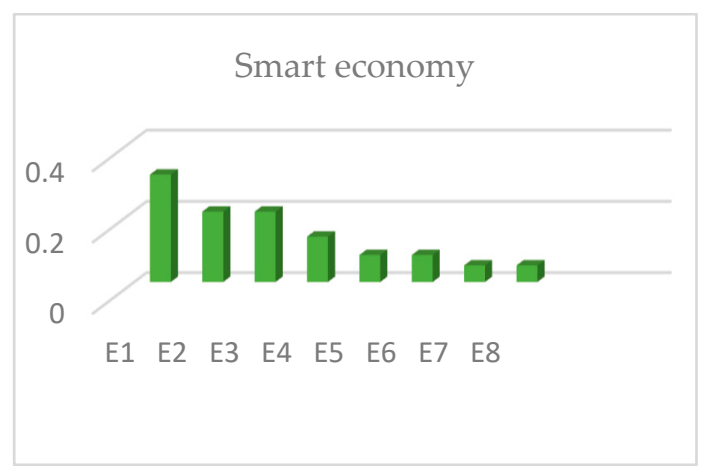

(a)

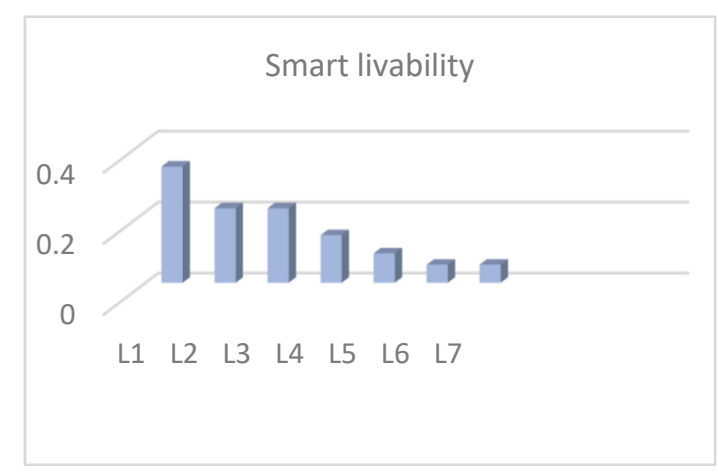

(b)

Figure 10. Graphical representation of the defuzzified weights of: (a) the smart economy sub-criteria (b) the smart livability sub-criteria. 


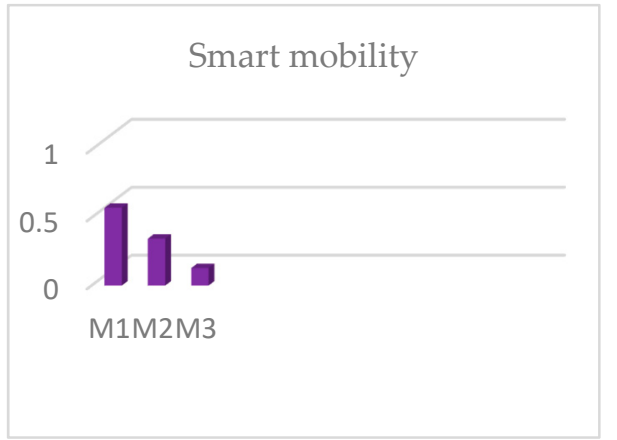

(a)

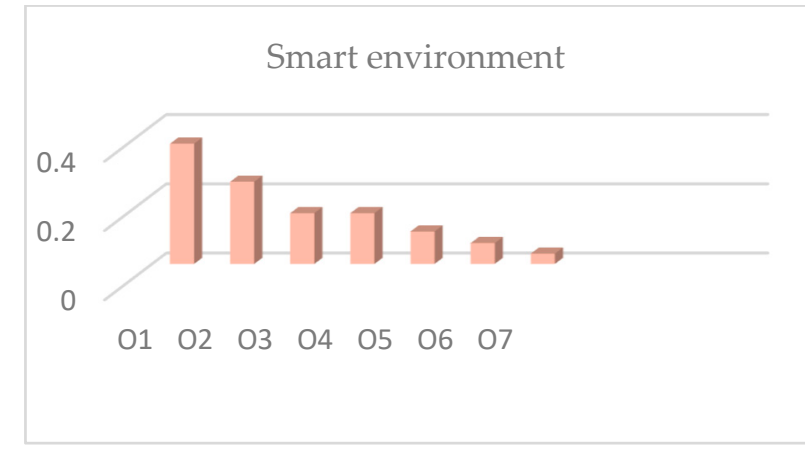

(b)

Figure 11. Graphical representation of the defuzzified weights of: (a) the smart mobility sub-criteria (b) the smart environment sub-criteria.

The complete list of aggregated final weights for each sub-criterion are given in Table 12.

Table 12. The final rank of sub-criteria for smart city.

\begin{tabular}{|c|c|c|c|}
\hline Sub-Criteria & $\mathbf{W}_{\mathbf{C}}$ & $\mathbf{W}_{\mathrm{SC}}$ & $\mathbf{W}_{\mathrm{C}}{ }^{*} \mathbf{W}_{\mathrm{SC}}$ \\
\hline Strategies and perspectives for smart city development $G_{1}$ & 0.3806 & 0.4766 & 0.1814 \\
\hline Citizens active participation in decision making $\mathrm{G}_{2}$ & 0.3806 & 0.2883 & 0.1097 \\
\hline Involvement of citizens in the community $C_{1}$ & 0.2484 & 0.3803 & 0.0945 \\
\hline Raising civic awareness $\mathrm{C}_{2}$ & 0.2484 & 0.2553 & 0.0634 \\
\hline Accessibility of services and e-government $\mathrm{G}_{3}$ & 0.3806 & 0.1533 & 0.0583 \\
\hline Management transparency and use of open-data $G_{4}$ & 0.3806 & 0.1533 & 0.0583 \\
\hline Integration of ICT infrastructure $\mathrm{M}_{1}$ & 0.0824 & 0.5728 & 0.0472 \\
\hline Strengthening individual citizen safety $\mathrm{L}_{1}$ & 0.1430 & 0.3272 & 0.0468 \\
\hline Self-employment fostering and entrepreneurship $E_{1}$ & 0.1430 & 0.3019 & 0.0432 \\
\hline A degree of citizens qualification and education $C_{3}$ & 0.2484 & 0.1559 & 0.0387 \\
\hline Affinity to life-long and e-learning $C_{4}$ & 0.2484 & 0.1559 & 0.0387 \\
\hline Affordable housing and good housing condition $\mathrm{L}_{2}$ & 0.1430 & 0.2099 & 0.0300 \\
\hline Utilities and infrastructure equipment $\mathrm{L}_{3}$ & 0.1430 & 0.2099 & 0.0300 \\
\hline Sustainable urban planning and management $\mathrm{O}_{1}$ & 0.0824 & 0.3472 & 0.0286 \\
\hline Innovative transport systems with non-motorized vehicles $\mathrm{M}_{2}$ & 0.0824 & 0.3456 & 0.0285 \\
\hline Innovations and strategic investment $\mathrm{E}_{2}$ & 0.1430 & 0.1977 & 0.0283 \\
\hline Economic opportunities for citizensE $E_{3}$ & 0.1430 & 0.1977 & 0.0283 \\
\hline Pollution control and environment protection $\mathrm{O}_{2}$ & 0.0824 & 0.2374 & 0.0196 \\
\hline Accessibility to healthcare services $\mathrm{L}_{4}$ & 0.1430 & 0.1341 & 0.0192 \\
\hline Productivity in economy $\mathrm{E}_{4}$ & 0.1430 & 0.1274 & 0.0182 \\
\hline Creativity, flexibility, and open-mindedness $C_{5}$ & 0.2484 & 0.0678 & 0.0168 \\
\hline Efficient water use $\mathrm{O}_{3}$ & 0.0824 & 0.1468 & 0.0121 \\
\hline Use of renewable energy sources $\mathrm{O}_{4}$ & 0.0824 & 0.1468 & 0.0121 \\
\hline Opportunities for education and training $\mathrm{L}_{5}$ & 0.1430 & 0.0829 & 0.0119 \\
\hline Transformation capacity and market flexibility $E_{5}$ & 0.1430 & 0.0758 & 0.0108 \\
\hline Economy promotion and market competitiveness $\mathrm{E}_{6}$ & 0.1430 & 0.0758 & 0.0108 \\
\hline Good local and international accessibility to city $\mathrm{M}_{3}$ & 0.0824 & 0.1290 & 0.0106 \\
\hline The social and ethnic diversity of citizens $\mathrm{C}_{6}$ & 0.2484 & 0.0344 & 0.0086 \\
\hline Energy efficiency buildings construction $\mathrm{O}_{5}$ & 0.0824 & 0.0938 & 0.0077 \\
\hline Social integration and recreation $\mathrm{L}_{6}$ & 0.1430 & 0.0509 & 0.0073 \\
\hline Development of culture and tourism $\mathrm{L}_{7}$ & 0.1430 & 0.0509 & 0.0073 \\
\hline Economy promotion and competitiveness $\mathrm{E}_{6}$ & 0.1430 & 0.0467 & 0.0067 \\
\hline Development of e-business and e-commerce $\mathrm{E}_{7}$ & 0.1430 & 0.0467 & 0.0067 \\
\hline Management and protection of natural resources $\mathrm{O}_{6}$ & 0.0824 & 0.0603 & 0.0050 \\
\hline Nature attractiveness of landscapes $\mathrm{O}_{7}$ & 0.0824 & 0.0300 & 0.0025 \\
\hline
\end{tabular}


Single triangular or trapezoidal fuzzy numbers overwhelm the central values. We did analyze with single fuzzy numbers and less relevant results were obtained. Therefore, in our research using IT2FS that fewer favors central values, we get results that give a more realistic reflection of the actual state. Figure 12 shows a diagram with the weights coefficients of key indicators for the development of a smart city in Serbia. The weights of the basic groups of criteria are marked with red color, while the weights of the sub-criterion are marked with green. The blue color shows the final weights of key indicators.

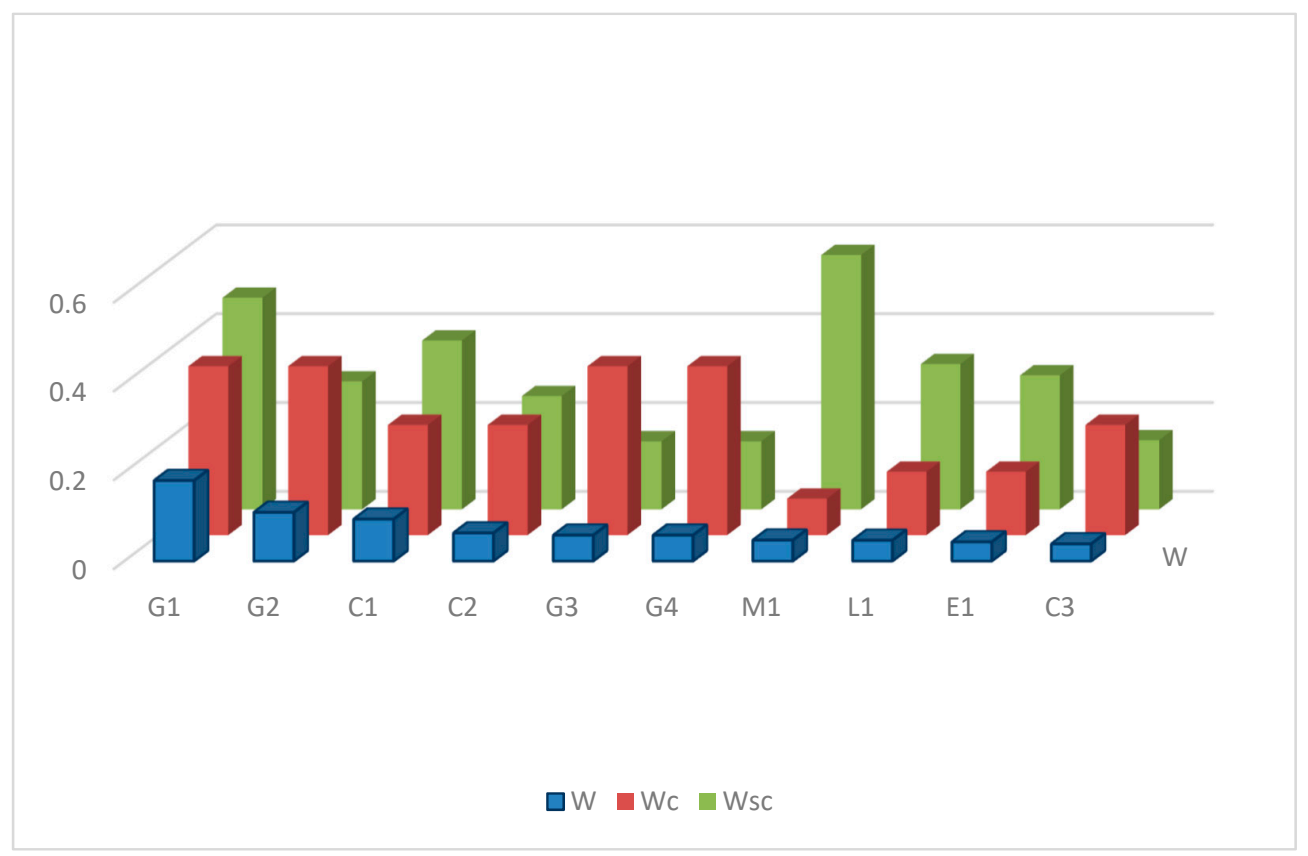

Figure 12. Weights of key indicators for smart city development.

\section{Measures to Implement Priorities}

The developed countries of western and eastern Europe that have already developed or implemented strategies for the development of a smart city consider the problems of the smart city in terms of the degree of improvement of the already existing development. Therefore, their researches are mostly related to examining the aspects of individual components of the smart city and their improvement.

Transformation of any environment into a smart city is a long process. The initial phase of the process and strategic development planning is an important prerequisite for the success of the transformation. The transformation of cities around the world is caused primarily by the entry of digital technology in all spheres of life and work, globalization and increasing urbanization. A successful transformation will result in creating clear visions of the future development of the city, creating a favorable business environment, efficient use of data, resilience to changes and sustainable development and a focus on the needs of the city's residents. Key factors for the success of digital transformation can be summarized by using three main principles: people, processes, and technologies.

- People - crucial to define the framework of a smart city is to define the meaning of the concept of "community" in a specific environment. Each community has its own identified needs and challenges, and their coexistence and mutual interactions constitute the framework within which the smart city development.

- Processes-if the process identifies the so-called "pain-points", they present important information about potential constraints in communication channels between city administration and communities. 
- Technologies-connections between people and processes, strategic and targeted applied technological solutions can greatly facilitate or even completely eliminate the inefficient and obstructive processes. In smart cities, technology is not the first, but the last step in creating technologically advanced and sustainable communities, based on understanding people and processes that make smart the environment.

The smart city concept has existed for more than 20 years, but very few ideas have reached the stage of realization in terms of the public service that the city provides to its citizens. The reasons are numerous and mainly attributable to the mismatch of infrastructure, legal barriers and the imposition of the solutions of the top-bottom approach. Final services, which should be implemented and used within the specific solutions of individual cities, never come to life because they do not reflect the real needs of citizens or industry, and often do not meet the infrastructure requirements. In order to avoid this practice for any initiative in the concept of a smart city, as is necessary to hold wide-ranging postulates:

- The engagement of citizens in creating and establishing a vision, using social networks, the media, digital technologies (on-line forums, workshops, etc.);

- Wishes should not replace proper project methodology and framework, and it is necessary to set measurable targets and select indicators;

- The lean methodology should have been applied wherever it is possible-especially if it concerns the development of new expansive infrastructure.

In the design and projects implemented within the framework of the Smart City concept, there is a complexity arising from the number of levels on which the project has to be applied. Due to the complexity of the structural problem solving, many projects in the field of smart city concept have failed, so it is necessary to define the level of the project at the stage of project preparation. We have created levels from more general to more specific: from the level of spatial and urban planning that defines the purposes of urban areas and the existence of appropriate urban functions through the implementation of infrastructure to increment living standards. This set of levels in the development of the concept is an attempt to introduce a hierarchical approach.

Five different levels of the project have shown in Figure 13.

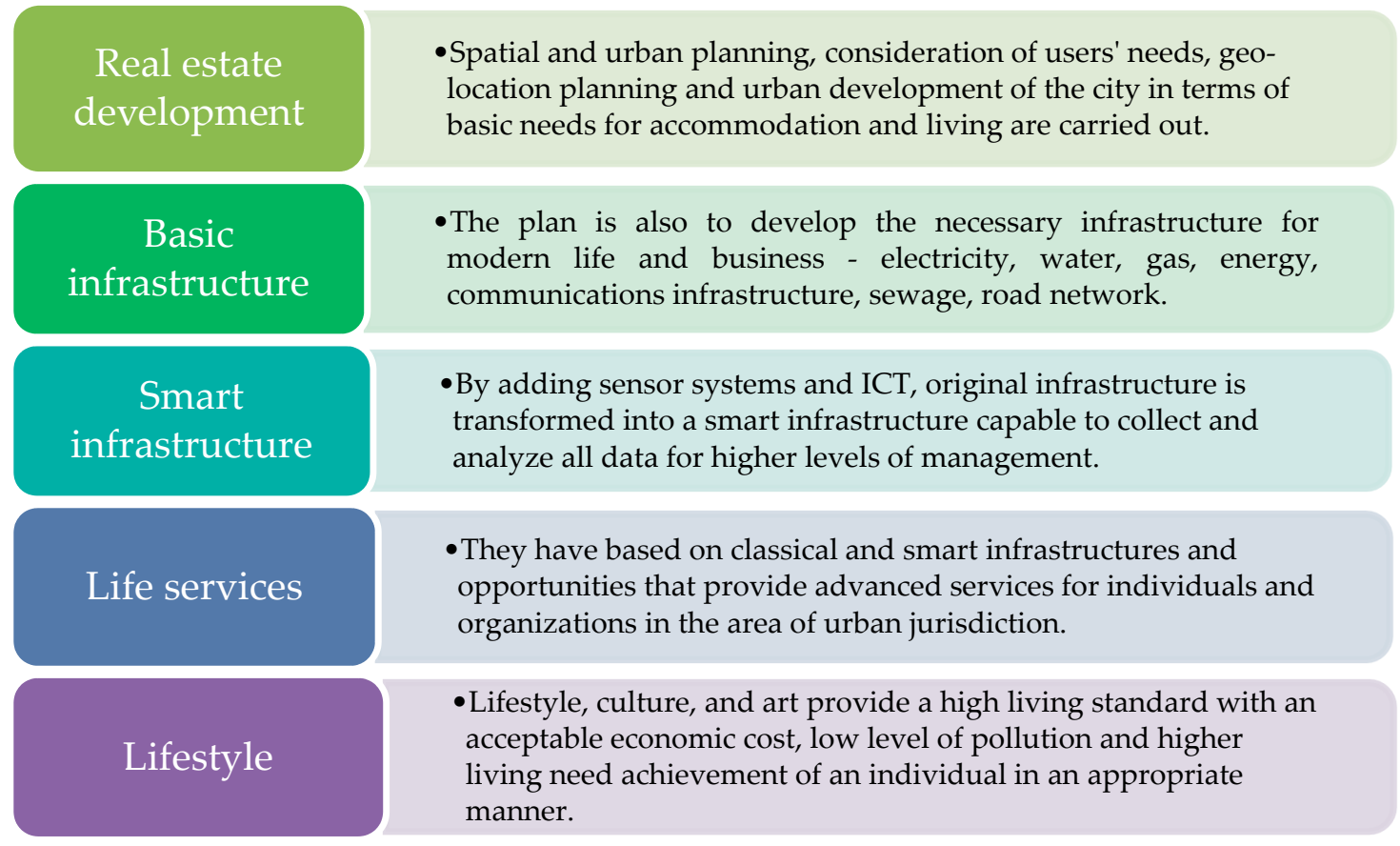

Figure 13. Levels of the smart city concept. 
The proposed method performs criteria ranking, using all available information in order to find an optimal approach in the development of the Smart City concept. By precise implementation, of applying the interval type-2 fuzzy sets method, were carried out. Key indicators of the smart cities in Serbia is given in Figure 14.

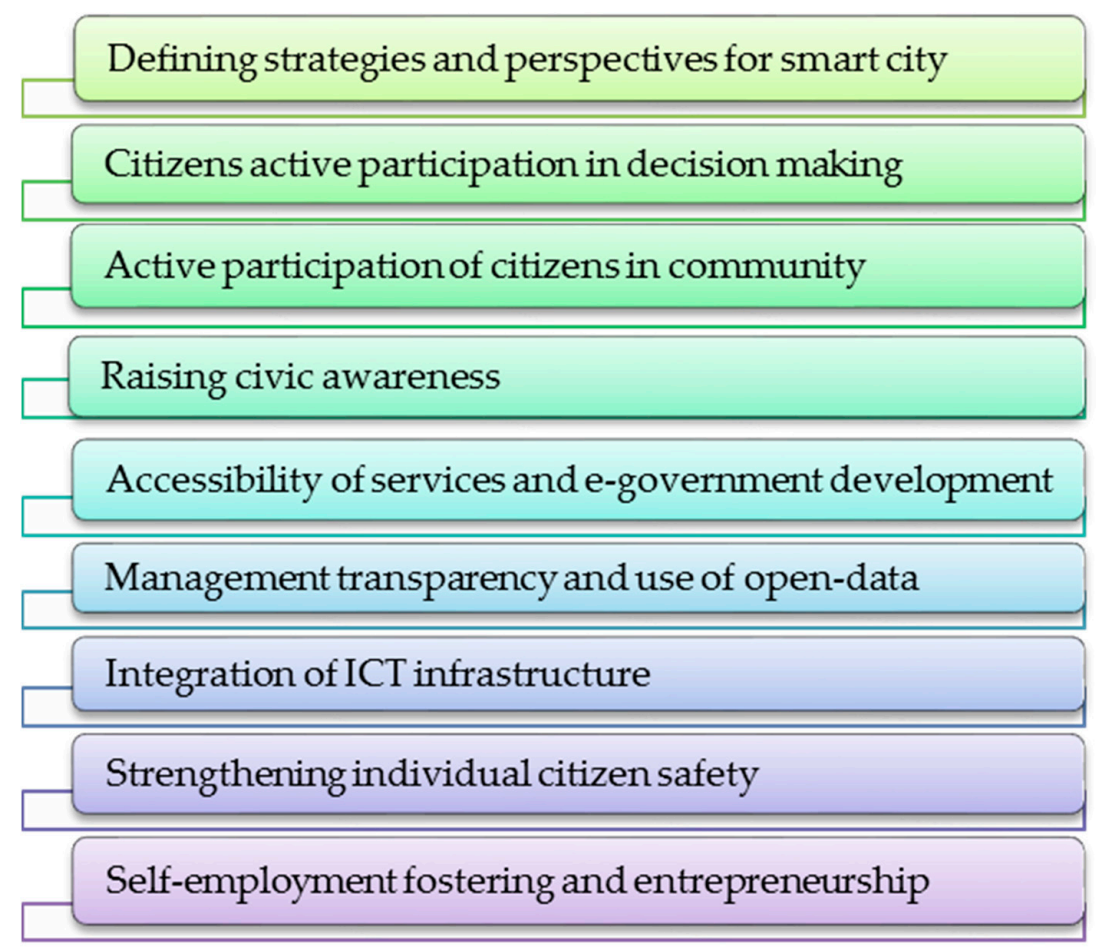

Figure 14. Key indicators of the development of smart cities in Serbia.

Bearing in mind the postulates and levels of the Smart City concept, as well as the key indicators, in order to succeed in establishing a smart and sustainable city, it is important to harmonize the local authorities' ambitions. The process will fail if the following conditions have not ensured as key tasks:

- The initiative for establishing a smart sustainable city must have a strong political consensus within the local authorities. The consensus has must be achieved through the selection of a competent leadership of the project, coordination between relevant stakeholders, joint decision-making, management of changes, joint problem overcoming. Responsibility and the ability to make quick decisions is the key to success.

- The set of goals must be clear and must enable the quantification and evaluation of the obtained results which can be easily presented to citizens. It is important to elaborate on the communication strategy of the project.

- The continuous evaluation of the results is essential for proving the value of the transformation process and achieving benefits for citizens. Selection of relevant key indicators considerably determines the quality of the results.

- Implementation of the public-private cooperation model, particularly civil society, universities, and local government, will be a guarantee of success. Planning must facilitate the development of scenarios and strategies of implementing the transformation, identification of the mutual benefits of all, and the economic effects of such cooperation are significant.

- A feasibility study must confirm the feasibility of the project and, more importantly, the long-term sustainability of all components.

- Citizens are significant participants in a smart, sustainable city. They are users of services and they can provide valuable data, ideas, and comments. 
The beginning of every smart city planning process is a smart city plan or strategy. There is a wide range of very divergent plans that are the starting point for the development of concrete projects, often having different ranges and covering different areas of expertise. However, they all have a common goal: reducing carbon emissions in cities using advanced ICT-based solutions. Like any strategy, it is important that strategic plans for smart cities are adapted to the needs, priorities, and constraints of their circumstances.

The basic goal of establishing a communication platform is to effectively connect a large number of devices and connect them to a range of services. In order to achieve real-time performance, efficient data processing is needed. Each city has unique attributes, and the development of each strategy must be tailored to vision and goals. Great potential lies in public participation. He's around us, but he needs to be activated to show his benefits. Motivating citizens to participate in policy-making processes to appreciate their fears and attitudes is quite a challenge. Only in this way can we create smart cities. Public consultation channels during the policy-making and law-making process must be open and modern, including online platforms that could facilitate simple public administration communication with business associations, civil society organizations, the academic community, and the general public. Developing consciousness means changes in all areas and at all levels, it means progress and humanization, as well as respect for social norms and rights. The humanization of life involves building a new way of life as a prerequisite for the development of ecologically smart cities. The Public Administration Reform Strategy confirms the intention of the Government of the Republic of Serbia to continue the transformation of the state administration in order to become a more organized, more efficient, transparent and service-oriented system. Their vision implies providing better management services in accordance with international regulations and the needs of service users. The concept of open administration implies a form of administration that in its essence encourages and supports the idea of free and open access to information that arises in the daily work of state administration, strives to enable full transparency of its data and processes, and promotes and improves cooperation with citizens, but also cooperation at different levels administration, thus improving its own responsibility. In conjunction with modern ICT technologies, the open administration leads to innovative strategies to change the way the government works, where the ultimate results are more effective institutions and a stronger democracy.

Individual safety is an important prerequisite for the development and transformation of cities into smart, and Serbia must find a way to strengthen the individual safety of citizens. In self-employment and entrepreneurship lies one of the key ways to overcome high unemployment in Serbia. Although it can be noted that certain efforts have been made to promote entrepreneurship in Serbia, this is not enough. One of the reasons is that all improvements had the result of push effects, which are more existential than progressive. However, more work needs to be done to pull the effects induced by the prosperity of the economy, creating entrepreneurial opportunities.

Given that there are no conditions for the development of the smart city concept in Serbia, the multi-criteria analysis is necessary in identifying the fields to be worked out in order to create optimal conditions. The obtained results regarding the case study of Serbia differ from similar studies applied to other countries in terms of research aspect, the existence of appropriate strategy for smart city development or degree of its implementation in practice. In similar studies which have to deal with MCDA and smart cities, the indicators are more specifically defined. Most of the studies favor the areas of smart environment or mobility as sectors that need to invest more, and watch in the future, while in Serbia without governance, it will not be possible to create a strategy for the development of a smart city.

\section{Conclusions}

In this paper, we have explored the broader framework of the concept of the development of smart cities. In the theoretical background, the paper tried to explain the most important aspects and challenges of the smart cities. We have tried to contribute to a small number of studies that have so 
far dealt with smart cities in Serbia. In terms of the applied methodology, the contribution can be recognized in the application of a concrete fuzzy hybrid method in the field of smart city development. Further, in Serbia, there are no researches based on multi-criteria analysis regarding the smart city. The smart city aims to initiate a process of sustainable development which takes into account the actual needs of stakeholders. A necessary analysis of the current situation and indicators of quality of life, long-term vision of the city and measurable goals, points to a common platform of the smart city and the sustainable city. Globalization, ecological disasters, and overcrowding are problems which mean that human society has to think about how to live in a smarter way. Some steps are being taken in Serbia, although the implementation is behind developed countries in Europe. By establishing a methodology that will help to find the optimal way for a sustainable and smart city in Serbia, our research is an attempt to model the concept of a smart city. In this paper, we analyzed the ranking of key indicators in developing the smart city concept using the hybrid fuzzy MCDM model based on Interval type-2 fuzzy sets. The ranking has considered six criteria groups (governance, citizens, economy, mobility, livability, and environment) and 35 sub-criteria. The top dominant measures are: defining strategies and perspectives of smart city development, citizen participation in decision-making and involvement in the local community. The conclusion is that the development of an appropriate strategy requires both affordable services and the development of e-government. Raising the level of awareness and education of citizens, along with monitoring and evaluation of results, should provide a good strategy for a smart, sustainable city. Entrepreneurship and the promotion of self-employment with the integration of ICT, citizen satisfaction, and with a high degree of qualifications and education, are further preconditions for creating the desired strategy. In addition to developing transparent management and use of open data, it is necessary to promote life-long learning too. From project identification and investment plan development through to the identification of financial mechanisms, pilot projects should be launched and the experiences of different cities exchanged. The smart city concept development strategy can be created using well-defined projects that create robust and transparent regulatory frameworks, give incentives for investment and set long-term goals for all participants. The aim of this paper is to support one such concept. The obtained results could be the basis of further research efforts taking into account the proposed levels and the key indicators.

Author Contributions: Conceptualization, M.R.M.; methodology, D.M.M. and M.R.M.; software, D.M.M.; validation, M.R.M., D.M.S. and D.M.M.; formal analysis, M.R.M. and D.M.M.; investigation, A.D.S. and M.R.M.; resources, A.D.S. and D.M.S.; data curation, D.M.M. and D.M.S.; writing-original draft preparation, M.R.M. and A.D.S.; writing - review and editing, D.M.M.; visualization, M.R.M. and A.D.S.; supervision, M.R.M. and D.M.M.; project administration, A.D.S. and D.M.S.; funding acquisition, D.M.S.

Funding: This research received no external funding.

Acknowledgments: This research was supported by the Serbian Ministry of Education and Science under grant number $174022,36045$.

Conflicts of Interest: The authors declare no conflict of interest.

\section{References}

1. Ahvenniemi, H.; Huovila, A.; Pinto-Seppa, I.; Airaksinen, M. What are the differences between sustainable and smart cities? Cities 2017, 60, 234-245. [CrossRef]

2. Yigitcanlar, T.; Kamruzzaman, M.; Foth, M.; Sabatini-Marques, J.; Costa, E.; Ioppoloe, G. Can cities become smart without being sustainable? A systematic review of the literature. Sustain. Cities Soc. 2019, 45, 348-365. [CrossRef]

3. Alkandari, A.; Alnasheet, M.; Alshekhly, I.F.T. Smart Cities: Survey. J. Adv. Comput. Sci. Technol. Res. 2012, 2, 79-90.

4. Golej, J. Smart growth and sustainable development: New trends in land development. In Proceedings of the International Scientific Conference People, Buildings and Environment, Kroměříž, Czech Republic, 15-17 October 2014; pp. 164-176. 
5. Lopes, I.M.; Oliveira, P. Can a small city be considered a smart city? Procedia Comput. Sci. 2017, 121, 617-624. [CrossRef]

6. Moser, C.; Wendel, T.; Carabias-Hütter, V. Scientific and Practical Understandings of Smart Cities. In Proceedings of the Conference REAL CORP, Vienna, Austria, 21-23 May 2014; pp. 507-514.

7. Eremia, M.; Toma, L.; Sanduleac, M. The Smart City Concept in the 21st Century. Procedia Eng. 2017, 181, 12-19. [CrossRef]

8. Hsi-Peng, L.; Chiao-Shan, C.; Hueiju, Y. Technology roadmap for building a smart city: An exploring study on methodology. Future Gener. Comput. Syst. 2019, 97, 727-742, In Press.

9. Guedes, A.L.A.; Alvarenga, J.C.; Goulart, M.S.S.; Rodriguez, M.V.R.; Soares, C.A.P. Smart Cities: The Main Drivers for Increasing the Intelligence of Cities. Sustainability 2018, 10, 3121. [CrossRef]

10. Marsal-Llacuna, M.L.; Segal, M.E. The Intelligenter Method (I) for making "smarter" city projects and plans. Cities 2016, 55, 127-138. [CrossRef]

11. Monzon, A. Smart Cities Concept and Challenges: Bases for the Assessment of Smart City Projects. Commun. Comput. Inf. Sci. 2015, 579, 17-31.

12. Apostolopoulos, P.A.; Tsiropoulou, E.E.; Papavassiliou, S. Demand response management in smart grid networks: A two-stage game-theoretic learning-based approach. Mob. Netw. Appl. 2018, 1-14. [CrossRef]

13. Falconer, G.; Mitchell, S. Smart City Framework: A Systematic Process for Enabling Smart + Connected Communities. Cisco Internet Business Solutions Group (IBSG), 2012. Available online: https://www.cisco. com/c/dam/en_us/about/ac79/docs/ps/motm/Smart-City-Framework.pdf (accessed on 27 June 2019).

14. Đukić, A.; Antonić, B. The concept of a smart city as response to climate changes. In Monograph Spatial, Ecological, Energy and Social Aspects of Cities Development and Climate Changes; Institute for Architecture and Urbanism Serbia: Belgrade, Serbia, 2016; pp. 15-32. ISBN 978-86-80329-85-7. (In Serbian)

15. European Parliament. Mapping Smart Cities in the EU: the Study; Policy Department A: Economic and Scientific Policy; European Parliament: Brussels, Belgium, 2014.

16. Wey, W.M.; Hsu, J. New Urbanism and Smart Growth: Toward achieving a smart National Taipei University District. Habitat Int. 2014, 42, 164-174. [CrossRef]

17. Dameri, R.P.; Cocchia, A. Smart City and Digital City: Twenty Years of Terminology Evolution. In Proceedings of the 10th Conference of the Italian Chapter of AIS (ITAIS), Universita Commercial Luigi Bocooni, Milan, Italy, 14 December 2013; pp. 1-8.

18. Susantia, R.; Soetomo, S.; Buchori, I.; Brotosunaryo, P.M. Smart Growth, Smart Cities and Density: In Search of The Appropriate Indicator for Residential Density in Indonesia. Procedia Soc. Behav. Sci. 2016, 227, 194-201. [CrossRef]

19. Mosannenzade, F.; Vettorato, D. Defining smart city: A conceptual framework based on keyword analysis. TeMA J. Land Use Mobil. Environ. 2014, 12, 683-694.

20. Papa, R.; Galderisi, A.; Vigo Majello, M.C.; Saretta, E. Smart and resilient cities: A systematic approach for developing cross-sectoral strategies in the face of climate change. TeMA J. Land Use Mobil. Environ. 2015, 8, 19-50.

21. Deakin, M. Smart cities: The state-of-the-art and governance challenge. Triple Helix 2014, 1, 7. [CrossRef]

22. Li, C.X.; Fong, P.S.W.; Dai, S.; Li, Y. Towards sustainable smart cities: An empirical comparative assessment and development pattern optimization in China. J. Clean. Prod. 2019, 215, 730-743. [CrossRef]

23. Judevicius, R.; Patasiene, I.; Patisius, M. Digital dimension of smart city: Critical analysis. Procedia-Soc. Behav. Sci. 2014, 156, 146-150. [CrossRef]

24. Care, S.; Trotta, A.; Care, R.; Rizzello, A. Crowdfunding for the development of smart cities. Bus. Horiz. 2018, 61, 501-509. [CrossRef]

25. Park, E.; Pobil, A.P.; Kwon, S.J. The Role of Internet of Things (IoT) in Smart Cities: Technology Roadmap-oriented Approaches. Sustainability 2018, 10, 1388. [CrossRef]

26. Batty, M. Big data, smart cities and city planning. Dialogues Hum. Geogr. 2013, 3, 247-279. [CrossRef]

27. Schuurman, D.; Baccarne, B.; De Maraz, L.; Mechnat, P. Smart Ideas for Smart Cities: Investigating Crowdsourcing for Generating and Selecting Ideas for ICT Innovation in a City Context. J. Theor. Appl. Electron. Commer. Res. 2012, 7, 49-62. [CrossRef]

28. Katsinis, G.; Tsiropoulou, E.; Papavassiliou, S. Multicell interference management in device to device underlay cellular networks. Future Internet 2017, 9, 44. [CrossRef] 
29. Chai, B.; Chen, J.; Yang, Z.; Zhang, Y. Demand response management with multiple utility companies: A two-level game approach. IEEE Trans. Smart Grid 2014, 5, 722-731. [CrossRef]

30. Lima, C.; Kimb, K.J.; Maglioc, P.P. Smart cities with big data: Reference models, challenges and considerations. Cities 2018, 82, 86-99. [CrossRef]

31. Milošević, M.; Dimić, V. Multi-criteria analysis in ICT implementation for Smart Cities. In Proceedings of the 7th International Scientific Conference Employment, Education and Entrepreneurship, EEE 2018, Belgrade, Serbia, 18-20 October 2018; pp. 83-105.

32. Barns, S. Smart cities and urban data platforms: Designing interfaces for smart governance. City Cult. Soc. 2018, 12, 5-12. [CrossRef]

33. Aina, Y.A. Achieving smart sustainable cities with GeoICT support: The Saudi evolving smart cities. Cities 2017, 71, 49-58. [CrossRef]

34. Desdemoustiera, J.; Crutzena, N.; Giffinger, R. Municipalities' understanding of the Smart City concept: An exploratory analysis in Belgium. Technol. Forecast. Soc. Chang. 2019, 142, 129-141. [CrossRef]

35. Yadav, G.; Mangla, S.K.; Luthra, S.; Rai, D.P. Developing a sustainable smart city framework for developing economies: An Indian context. Sustain. Cities Soc. 2019, 47, 101462. [CrossRef]

36. Giffinger, R.; Fertner, C.; Kramar, H.; Kalasek, R.; Pichler-Milanovic, N.; Meijers, E. Smart Cities-Ranking of European Medium Sized; Centre of Regional Science: Vienna, Austria, 2007.

37. Giovannella, C.; Dascalu, M.; Scaccia, F. Smart City Analytics: State of the art and future perspectives. Int. Des. Archit. J. 2014, 20, 72-87.

38. Tahir, Z.; Malek, J.A. Main criteria in the development of smart cities determined using analytical method. J. Malays. Inst. Plan. 2016, 14, 1-14. [CrossRef]

39. Lombardi, P. New challenges in the evaluation of Smart Cities. Netw. Ind. Q. 2011, 13, 8-10.

40. Ruhlandt, R.W.S. The governance of smart cities: A systematic literature review. Cities 2018, 81, 1-23. [CrossRef]

41. Glasmeier, A.; Christopherson, S. Thinking about smart cities. Camb. J. Reg. Econ. Soc. 2015, 8, 3-12. [CrossRef]

42. Mellouli, S.; Luna-Reyes, L.F.; Zhang, J. Smart government, citizen participation and open data. Inf. Polity 2014, 19, 1-4. [CrossRef]

43. Adreani, S.; Kalchschmidt, M.; Pinto, R.; Sayegh, A. Reframing technologically enhanced urban scenarios: A design research model towards human centered smart cities. Technol. Forecast. Soc. Chang. 2019, 142, $15-25$. [CrossRef]

44. Ju, J.; Liu, L.; Feng, Y. Citizen-centered big data analysis-driven governance intelligence framework for smart cities. Telecommun. Policy 2018, 42, 881-896. [CrossRef]

45. Aguilera, U.; Pena, O.; Belmonte, O.; Ilpina, D.L. Citizen-centric data services for smarter cities. Future Gener. Comput. Syst. 2017, 76, 234-247. [CrossRef]

46. Lee, J.; Lee, H. Developing and validating a citizen-centric typology for smart city services. Gov. Inf. Q. 2014, 31, 93-105. [CrossRef]

47. Silva, N.B.; Khan, M.; Han, K. Towards sustainable smart cities: A review of trends, architectures, components, and open challenges in smart cities. Sustain. Cities Soc. 2018, 38, 697-713. [CrossRef]

48. Batty, M.; Axhausen, K.W.; Giannotti, F.; Pozdnoukhov, A.; Bazzani, A.; Wachowicz, M.; Ouzounis, G.; Portugali, Y. Smart cities of the future. Eur. Phys. J. Spec. Top. 2012, 214, 481-518. [CrossRef]

49. Monfaredzadeh, T.; Krueger, K. Investigating social factor of sustainability in a smart city. Procedia Eng. 2015, 118, 1112-1118. [CrossRef]

50. Ardito, A.; Ferraris, A.; Petruzzelli, A.M.; Bresciani, S.; Giudicee, M.D. The role of universities in the knowledge management of smart city projects. Technol. Forecast. Soc. Chang. 2019, 142, 312-321. [CrossRef]

51. Dameri, R.P. Searching for Smart City definition: A comprehensive proposal. Int. J. Comput. Technol. 2013, 11, 2544-2551. [CrossRef]

52. Anand, P.B.; Navio-Marco, J. Governance and economics of smart cities: Opportunities and challenge. Telecommun. Policy 2018, 42, 795-799. [CrossRef]

53. Batagan, L. Indicators for economic and social development of future smart cities. J. Appl. Quant. Methods 2011, 6, 27-34.

54. Okuda, T.; Hirasawa, S.; Matsukuma, N.; Fukumoto, T.; Shimura, A. Smart Mobility for Smart Cities. Hitachi Rev. 2012, 61, 141-146. 
55. Docherty, I.; Marsden, G.; Anable, J. The governance of smart mobility. Transp. Res. Part A 2018, 115, 114-125. [CrossRef]

56. Aleta, N.B.; Alonso, C.M.; Ruiz, R.M.A. Smart Mobility and Smart Environment in the Spanish cities. Transp. Res. Procedia 2017, 24, 163-170. [CrossRef]

57. Pinna, F.; Masala, F.; Garau, C. Urban Policies and Mobility Trends in Italian Smart Cities. Sustainability 2017, 9, 494. [CrossRef]

58. Milošević, D.; Stanojević, A.; Milošević, M. AHP method in the function of logistic in development of smart cities model. In Proceedings of the 6th International Conference: Transport and Logistic Til, Niš, Serbia, 25-26 May 2017; pp. 287-294.

59. Behrendt, F. Cycling the Smart and Sustainable City: Analyzing EC Policy Documents on Internet of Things, Mobility and Transport, and Smart Cities. Sustainability 2019, 11, 763. [CrossRef]

60. Cassandras, C.G. Automating mobility in smart cities. Annu. Rev. Control 2017, 44, 1-8. [CrossRef]

61. Stephanedes, J.Y.; Golias, M.P.E.; Dedes, G.; Douligeris, C.; Mishra, S. Challenges, Risks and Opportunities for Connected Vehicle Services in Smart Cities and Communities. IFAC Pap. 2019, 51, 139-144.

62. Lin, C.; Zhao, G.; Yu, C.; Wu, Y.J. Smart City Development and Residents' Well-Being. Sustainability 2019, 11, 676. [CrossRef]

63. Sofeska, E. Understanding the Livability in a City Through Smart Solutions and Urban Planning Toward Developing Sustainable Livable Future of the City of Skopje. Procedia Environ. Sci. 2017, 37, 442-453. [CrossRef]

64. Aguaded-Ramirez, E. Smart City and Intercultural Education. Procedia Soc. Behav. Sci. 2017, 237, $326-333$. [CrossRef]

65. Khan, S.; Woo, M.; Nam, K.; Chathoth, P.K. Smart City and Smart Tourism. Sustainability 2017, 9, 2279. [CrossRef]

66. Bajaj, R.; Sharma, V. Smart Education with artificial intelligence based determination of learning styles. Procedia Comput. Sci. 2018, 132, 834-842. [CrossRef]

67. Selimi, A.; Milošević, M.; Saračević, M. AHP-TOPSIS Model as a Mathematical Support in the Selection of Project from Aspect of Mobility-Case Study. J. Appl. Math. Comput. 2018, 2, 257-265.

68. Chen, Y.; Han, D. Water quality monitoring in smart city: A pilot project. Autom. Constr. 2018, 89, $307-316$. [CrossRef]

69. Dostal, Z.; Ladanyi, L. Demands on energy storage for renewable power sources. J. Energy Storage 2018, 18, 250-255. [CrossRef]

70. Milošević, A.; Milošević, M.; Milošević, D.; Selimi, A. Ahp multi-criteria method for sustainable development in construction. In Proceedings of the 4th International Conference, Contemporary Achievements in Civil Engineering, Subotica, Serbia, 22 April 2016; pp. 929-938.

71. Milošević, M.; Milošević, D.; Dimić, V.; Stević, D.; Stanojević, A. The analysis of energy efficiency indicators and renewable energy sources for existing buildings. MKOIEE 2017, 5, 205-212.

72. Milošević, M.; Stanojević, A.; Milošević, A.; Milošević, D. Multi-criteria analysis of energy efficiency by AHP method in planning and architectural design. In Proceedings of the STEPGRAD2016, Banja Luka, Bosnia and Herzegovina, 18 February 2016; pp. 295-302.

73. Milošević, M.; Milošević, A.; Milošević, D.; Stanojević, A.; Dimić, V. Multicriteria analysis of contemporary materials for energy-efficient buildings. In Proceedings of the SFERA2016, Mostar, Bosnia and Herzegovina, 2 October 2016; pp. 46-51.

74. Milošević, D.; Milošević, M.; Stanojević, A.; Dimić, V.; Milošević, A. Application of FAHP Method in the Process of Building Construction from the Aspect of Energy Efficiency. In Proceedings of the 4th International Conference Mechanical Engineering in XXI Century, Niš, Serbia, 19-20 April 2018; pp. 271-276.

75. Batova, E. The distinctive features of "smart" buildings. Procedia Eng. 2015, 111, 103-107. [CrossRef]

76. O’Dweyer, E.; Pan, I.; Acha, S.; Shah, N. Smart energy systems for sustainable smart cities: Current developments, trends and future directions. Appl. Energy 2019, 237, 581-597. [CrossRef]

77. Zhang, W.; Liu, F.; Fan, R. Improved thermal comfort modeling for smart buildings: A data analytics study. Electr. Power Energy Syst. 2018, 103, 634-643. [CrossRef]

78. Pucar, M.; Nenković-Riznić, M.; Petrovic, S.; Brankov, B. The role of architects and urban planners in the formation of the concept and functioning of smart cities. In Proceedings of the 1st International Scientific Conference of Urban Planning (ICUP), Nis, Serbia, 18-19 November 2016; pp. 259-267. 
79. Vasilic, M. Operationalisation of "smart" city concept on the example of Serbia. Sociology 2018, 60, 518-537. (In Serbian)

80. Lazaroiu, G.C.; Roscia, M.C. Definition methodology for the smart cities model. Energy 2012, 47, $326-332$. [CrossRef]

81. Statistical Office of the Republic of Serbia. Statistical Yearbook of the Republic of Serbia; Republic Institute of Statistics: Belgrade, Serbia, 2018. (In Serbian)

82. Government of the Republic of Serbia. National Strategy for Sustainable Development; Government of the Republic of Serbia: Belgrade, Serbia, 2008. (In Serbian)

83. Zdravković, A.; Nikolić, D.; Bradić-Martinović, A. Analysis of the Privatization Model in Serbia. In Proceedings of the End of Privatization, Implications for Economic Development and Unemployment in Serbia, Belgrade, Serbia, 4 February 2010; pp. 278-287. (In Serbian).

84. Ministry of Construction, Transport and Infrastructure. Sustainable and Integrated Urban Development Strategy of Republic of Serbia Until 2030; Ministry of Construction, Transport and Infrastructure: Belgrade, Serbia, 2018; ISBN 978-86-900093-2-9.

85. Katic, A.; Stankovic, J.; Malenkovic, N. Smart cities initiative-challenge for Serbia, Proceedings of the IVth International Scientific Conference Climate Change, Economic Development. Environ. People 2015, 2, 66-73.

86. Hernández-Moreno, S.; De Hoyos-Martínez, J. Indicators of urban sustainability in Mexico. Theor. Empir. Res. Urban Manag. 2010, 7, 46-60.

87. Science for Environment Policy. In-Depth Report 12: Indicators for Sustainable Cities; European Commission: Brussels, Belgium, 2018. [CrossRef]

88. Vasiljević-Blagojević, M.; Marinković, S.; Perčić, K.; Lučić, V. The transition and the problem of brain drain from the perspective of students of a private university. Teach. Upbringing 2016, 65, 197-210. (In Serbian)

89. Vranić, P.; Vasilevska, L. Hybrid spatialities: Multi-storey extensions of socialist blocks of flats under post-socialist transition in Serbia, the case of Nis. Urban Stud. 2015, 53, 1261-1277. [CrossRef]

90. Spatial Development Strategy of the Republic of Serbia 2009-2013-2020. Ministry of Environment and Spatial Planning; Republic Agency for Spatial Planning: Belgrade, Serbia, 2009. (In Serbian)

91. Dimić, V.; Milošević, M.; Milošević, D.; Stević, D. Adjustable Model of Renewable Energy Projects for Sustainable Development: A Case Study of the Nišava District in Serbia. Sustainability 2018, 10, 775. [CrossRef]

92. Zadeh, L.A. Fuzzy sets. Inf. Control 1965, 8, 338-353. [CrossRef]

93. Zadeh, L.A. The concept of a linguistic variable and its application to approximate reasoning. Inf. Sci. 1975, 8, 199-249. [CrossRef]

94. Mendel, J.M.; John, R.B. Type-2 fuzzy sets made simple. IEEE Trans. Fuzzy Syst. 2002, 10, 117-127. [CrossRef]

95. Mendel, J.M.; John, R.I.; Liu, F. Interval type-2 fuzzy logic systems made simple. IEEE Trans. Fuzzy Syst. 2006, 14, 808-821. [CrossRef]

96. Sonera, O.; Celik, E.; Akyuz, E. Application of AHP and VIKOR methods under interval type 2 fuzzy environment in maritime transportation. Ocean Eng. 2017, 129, 107-116. [CrossRef]

97. Dereli, T.; Baykasoglu, A.; Altun, K.; Durmusoglu, A.; Turksen, I.B. Industrial applications of type-2 fuzzy sets and systems: A concise review. Comput. Ind. 2011, 62, 125-137. [CrossRef]

98. Dereli, T.; Altun, K. Technology evaluation through the use of interval type-2 fuzzy sets and systems. Comput. Ind. Eng. 2011, 65, 624-633. [CrossRef]

99. Celik, E.; Gul, M.; Aydin, N.; Gumus, A.T.; Guneri, A.F. A comprehensive review of multi criteria decision making approaches based on interval type-2 fuzzy sets. Knowl.-Based Syst. 2015, 85, 329-341. [CrossRef]

100. Castillo, O.; Melin, P. A review on the design and optimization of interval type-2 fuzzy controllers. Appl. Soft Comput. 2012, 12, 1267-1278. [CrossRef]

101. Castillo, O.; Melin, P. Optimization of type-2 fuzzy systems based on bio-inspired methods: A concise review. Inf. Sci. 2012, 205, 1-19. [CrossRef]

102. Chen, S.M.; Lee, L.W. Fuzzy multiple attributes group decision-making based on the interval type-2 TOPSIS method. Expert Syst. Appl. 2010, 37, 2790-2798. [CrossRef]

103. Chen, T.Y.; Chang, C.H.; Lu, J.F.R. The extended QUALIFLEX method for multiple criteria decision analysis based on interval type-2 fuzzy sets and applications to medical decision making. Eur. J. Oper. Res. 2013, 226, 615-625. [CrossRef] 
104. Gul, M.; Celik, E.; Gumus, A.T.; Guneri, A.F. Emergency department performance evaluation by an integrated simulation and interval type-2 fuzzy MCDM-based scenario analysis. Eur. J. Oper. Res. 2016, 10, 196-223. [CrossRef]

105. Saaty, T.L. The Analytic Hierarchy Process; McGraw-Hill: New York, NY, USA, 1980.

106. Buckley, J.J. Fuzzy hierarchical analysis. Fuzzy Sets Syst. 1985, 17, 233-247. [CrossRef]

107. Kahraman, C.; Oztaysi, B.; Sari, I.U.; Turanoglu, E. Fuzzy analytic hierarchy process with interval type-2 fuzzy sets. Knowl.-Based Syst. 2014, 59, 48-57. [CrossRef]

108. Abdullah, L.; Najib, L. A new type-2 fuzzy set of linguistic variables for the fuzzy analytic hierarchy process. Expert Syst. Appl. 2014, 41, 3297-3305. [CrossRef]

109. Kuo, M.S.; Liang, G.S. A soft computing method of performance evaluation with MCDM based on interval-valued fuzzy numbers. Appl. Soft Comput. 2012, 12, 476-485. [CrossRef]

110. Ghorabaee, M.K. Developing an MCDM method for robot selection with interval type-2 fuzzy sets. Robot. Comput.-Integr. Manuf. 2016, 37, 221-232. [CrossRef]

111. Dinçer, H.; Yüksel, S.; Korsakienè, R.; Raišienė, A.G.; Bilan, Y. IT2 Hybrid Decision-Making Approach to Performance Measurement of Internationalized Firms in the Baltic States. Sustainability 2019, 11, 296. [CrossRef]

(C) 2019 by the authors. Licensee MDPI, Basel, Switzerland. This article is an open access article distributed under the terms and conditions of the Creative Commons Attribution (CC BY) license (http://creativecommons.org/licenses/by/4.0/). 